\title{
Loss of Bcl-G, a Bcl-2 family member, augments the development of inflammation-associated colorectal cancer
}

\author{
Paul M. Nguyen ${ }^{1,2} \cdot$ Laura F. Dagley, $^{1,2} \cdot$ Adele Preaudet $^{1} \cdot$ Nga Lam $^{1,2} \cdot$ Maybelline Giam $^{1,2} \cdot$ Ka Yee Fung $^{1,2}$. \\ Kaheina Aizel ${ }^{1,2} \cdot$ Gemma van Duijneveldt $^{1,2} \cdot$ Chin Wee Tan $\mathbb{D}^{1,2} \cdot$ Yumiko Hirokawa $^{1,2} \cdot$ Hon Yan K. Yip ${ }^{1,3}$. \\ Christopher G. Love ${ }^{1,2,4}$ - Ashleigh R. Poh ${ }^{1,2,5}$ - Akshay D' Cruz ${ }^{1,2} \cdot$ Charlotte Burstroem $^{1} \cdot$ Rebecca Feltham ${ }^{1,2}$. \\ Suad M. Abdirahman ${ }^{1,2} \cdot$ Kristy Meiselbach $^{1,2} \cdot$ Ronnie Ren Jie Low $\mathbb{D}^{1,2} \cdot$ Michelle Palmieri $^{1,2} \cdot$ Matthias Ernst $^{5}$. \\ Andrew I. Webb ${ }^{1,2} \cdot$ Tony Burgess ${ }^{1,2} \cdot$ Oliver M. Sieber $^{1,2,6,7} \cdot$ Philippe Bouillet $^{1,2} \cdot$ Tracy L. Putoczki $^{1,2}$
}

Received: 2 January 2019 / Revised: 6 June 2019 / Accepted: 17 June 2019 / Published online: 11 July 2019

(c) The Author(s) 2019. This article is published with open access

\begin{abstract}
Gastrointestinal epithelial cells provide a selective barrier that segregates the host immune system from luminal microorganisms, thereby contributing directly to the regulation of homeostasis. We have shown that from early embryonic development Bcl-G, a Bcl-2 protein family member with unknown function, was highly expressed in gastrointestinal epithelial cells. While Bcl-G was dispensable for normal growth and development in mice, the loss of Bcl-G resulted in accelerated progression of colitisassociated cancer. A label-free quantitative proteomics approach revealed that Bcl-G may contribute to the stability of a mucin network, which when disrupted, is linked to colon tumorigenesis. Consistent with this, we observed a significant reduction in Bcl-G expression in human colorectal tumors. Our study identifies an unappreciated role for Bcl-G in colon cancer.
\end{abstract}

\section{Introduction}

Defects in the single layer of epithelial cells that line the gastrointestinal (GI) tract are implicated in the pathogenesis

These first authors contributed equally: Paul M. Nguyen, Laura F. Dagley, Adele Preaudet

These senior authors contributed equally: Philippe Bouillet, Tracy L. Putoczki

Edited by R. Johnstone

Supplementary information The online version of this article (https:// doi.org/10.1038/s41418-019-0383-9) contains supplementary material, which is available to authorized users.

Philippe Bouillet

bouillet@wehi.edu.au

$\checkmark$ Tracy L. Putoczki

putoczki.t@wehi.edu.au

1 The Walter and Eliza Hall Institute of Medical Research, Parkville, VIC 3052, Australia

2 The Department of Medical Biology, The University of Melbourne, Melbourne, VIC 3050, Australia

3 Now located at Monash Biomedicine Discovery Institute and Department of Biochemistry and Molecular Biology, Monash of inflammatory bowel disease (IBD) and colorectal cancer (CRC). In IBD patients, epithelial apoptosis is greatly enhanced at acute inflammatory sites and is associated with mucosal ulceration [1]. In parallel, persistent oxidative damage, as a result of the chronic inflammatory environment created by mucosal ulcers, can trigger mutagenic events in GI epithelial cells [2]. As a result, IBD patients have an increased risk of developing CRC [3].

BCL-G, also known as BCL2L14, is a poorly-studied member of the Bcl-2 family of proteins. The Bcl2 family is conserved throughout mammalian species, and each member harbors up to four Bcl-2 homology (BH) domains. Multi-domain pro-apoptotic proteins Bak and Bax trigger

University, Clayton, VIC 3800, Australia

4 Research Division, Peter MacCallum Cancer Centre, 305 Grattan St, Melbourne, Australia

5 Olivia Newton-John Cancer Research Institute, and School of Cancer Medicine, La Trobe University, Heidelberg, VIC 3084, Australia

6 Department of Surgery, The University of Melbourne, Melbourne, VIC 3052, Australia

7 Department of Biochemistry \& Molecular Biology, Monash University, Clayton, VIC 3800, Australia 
permeabilization of the mitochondrial membrane and the initiation of the intrinsic cell-death cascade [4]. Bcl-2, Bcl$\mathrm{X}_{\mathrm{L}}, \mathrm{Bcl}-\mathrm{w}, \mathrm{Mcl}-1$, and A1 form the pro-survival subgroup, and each contain four $\mathrm{BH}$ domains (BH1 to $\mathrm{BH} 4)$. These proteins bind to Bak and Bax, thereby inhibiting their function [5]. Pro-apoptotic BH3-only proteins Bad, Bid, Bik, Bim, Bmf, Hrk, Noxa, and Puma only contain the BH3 domain, which allows them to bind to and inhibit the prosurvival proteins, with some of them also described as direct activators of Bax and Bak [4, 6]. It is well established that the fate of a cell depends on the balance between the prosurvival and pro-apoptotic activities within this family, and their control of the integrity of mitochondria. The release of mitochondrial cytochrome $\mathrm{c}$ into the cytoplasm is the defining event that triggers the apoptotic cascade leading to cell death.

In humans (h) there are two BCL-G isoforms, hBCL-Gs and $\mathrm{hBCL}-\mathrm{G}_{\mathrm{L}}$, generated by alternative splicing [7]. hBCL$\mathrm{G}_{\mathrm{L}}$ contains $\mathrm{BH} 2$ and $\mathrm{BH} 3$ domains, with no other members of the Bcl-2 family containing only these two domains [7]. $\mathrm{hBCL}-\mathrm{G}_{\mathrm{S}}$ only harbors the $\mathrm{BH} 3$ domain, which is recognized as the critical death domain, leading to the suggestion that it is a member of the pro-apoptotic Bcl-2 family subgroup [7]. Overexpression of $\mathrm{hBCL}-\mathrm{G}_{\mathrm{S}}$ has been linked to cell death due to the capacity of its $\mathrm{BH} 3$ domain to neutralize the function of $\mathrm{BCL}-\mathrm{X}_{\mathrm{L}}$, this effect was less pronounced with $\mathrm{hBCL}-\mathrm{G}_{\mathrm{L}}$ [7]. In contrast, the $\mathrm{BH} 2$ domain from $\mathrm{hBCL}-\mathrm{G}_{\mathrm{L}}$ has been suggested to inhibit its interaction with BCL- $X_{L}$ [7]. In mice $(\mathrm{m})$, only one form of Bcl-G exists, which is $68 \%$ identical to $\mathrm{hBCL}-\mathrm{G}_{\mathrm{L}}$ and is expressed in similar tissues $[7,8]$. Interestingly, while $\mathrm{mBcl}-\mathrm{G}$ is highly expressed in the epithelial cells lining the GI tract, its role in this cell population is not known [8]. $\mathrm{mBcl}-\mathrm{G}$ does not interact with the pro-survival members of the Bcl-2 family through its $\mathrm{BH} 3$ domain, suggesting that it is not directly involved in the intrinsic cell-death pathway [7,9]. Similarly, hBcl- $\mathrm{G}_{\mathrm{L}}$ did not induce cytoprotective properties when directly compared to $\mathrm{Bcl}-2$ and $\mathrm{Bcl}-\mathrm{X}_{\mathrm{L}}$ [7]. The evolutionary significance of the potentially divergent function of the two hBCL-G isoforms remains unclear.

$B C L-G$ is located on chromosome $12 \mathrm{p} 12$, which is lost in prostate cancers, ovarian cancers, and childhood acute lymphocytic leukemias [10-13]. Based on these observations, it has been assumed that BCL-G has a tumor suppressive function, although this has not formally been shown. We find that in mice devoid of $\mathrm{Bcl}-\mathrm{g}$ the progression of colitisassociated cancer (CAC) is enhanced. Interestingly, we find that Bcl-G may contribute to regulation of the mucin network, which is essential to epithelial barrier function and, when disrupted, is known to contribute to CRC progression. The tumor suppressive phenotype associated with $B c l-g$ is consistent with the observation that $B C L-G$ expression is reduced in late stage human CRC tumors.

\section{Results}

\section{Loss of Bcl-G augments colitis-associated cancer}

Bcl-G is expressed by colonic epithelial cells as early as embryonic day 18.5 (E18.5) (Fig. 1a) and remains highly expressed by epithelial cells lining the colonic crypts of adult mice (Fig. 1b). Surprisingly, naïve $\mathrm{Bcl}^{-g^{-/}}$mice had normal colonic crypt architecture (Supplemental Fig. 1a), with no significant differences in the individual crypt lengths when compared to littermate WT mice (Supplemental Fig. 1b). This suggests that Bcl-G is not required for the normal proliferative turnover of colonic epithelial cells. This observation was validated by a lack of change in the number of epithelial cells entering S-phase, indicated by BrdU incorporation (Fig. 1c, d). We also observed no change in the number of cleaved Caspase-3-positive cells in the differentiated surface epithelium or within the proliferative zone of crypts (Fig. 1e, f), indicating that loss of Bcl-G does not affect normal apoptosis. Moreover, there was no change in the expression of other $\mathrm{Bcl}-2$ family members within the colon of $\mathrm{Bcl}-\mathrm{g}^{-1-}$ mice, making it unlikely that the function of Bcl-G in adult colonic crypts was masked by compensatory expression of other members of the Bcl-2 protein family (Fig. 1g).

We aged $\mathrm{Bcl}_{\mathrm{g}} \mathrm{g}^{-/-}$mice beyond one year and collected the entire GI tract to monitor for spontaneous tumor formation; however, no sporadic tumors were observed (data not shown). We next tested the hypothesis that loss of Bcl-G may predispose mice to tumor formation by subjecting $\mathrm{Bcl}-\mathrm{g}$ ${ }^{-1-}$ and WT mice to the CAC model (Fig. 2a), whereby a single injection of the alkylating mutagen azoxymethane (AOM) leads to the sporadic induction of missense mutations in the Ctnbl gene in colonic epithelial cells, resulting in stabilization of $\beta$-catenin and aberrant activation of the Wnt signaling pathway $[14,15]$. In this model, repetitive oral administration of the luminal irritant dextran sulfate sodium (DSS), which induces 'flares' of acute inflammation that mimic the mucosal damage observed in IBD patients, triggers the development of colonic tumors [16]. Monitoring of CAC progression by endoscopy showed that tumors appeared earlier and grew larger in $\mathrm{Bcl}_{-} \mathrm{g}^{-/-}$mice than in their WT littermates (Fig. 2b). This was further apparent on autopsy, where overall colonic tumor number and burden (Fig. 2c, d) were significantly increased in $\mathrm{Bcl}_{-} \mathrm{g}^{-1-}$ mice. This observation suggests a potential tumor suppressive function for Bcl-G in the colon.

\section{Loss of Bcl-G does not alter sporadic gastrointestinal tumor onset or progression}

Since Bcl-G is also highly expressed by epithelial cells of the small intestine in adult mice (Fig. 3a), we crossed $\mathrm{Bcl}-\mathrm{g}^{-/-}$ 
Fig. 1 Gastrointestinal homeostasis is unperturbed in $B c l-g^{-1-}$ mice. a Representative Bcl-G immunohistochemistry of an E18.5 C57BL/6 mouse embryo (left; Scale bar: $2 \mathrm{~mm}$ ). Representative images of the gastrointestinal epithelial cells of the small intestine (middle) and colon (right) are shown. Scale bar: $100 \mu \mathrm{m}$. b Representative immunohistochemistry for Bcl$\mathrm{G}$ in the distal colon of 8-weekold WT and $\mathrm{Bcl}-\mathrm{g}^{-/-}$mice.

Scale bar: $0.5 \mathrm{~mm}$, inset $50 \mu \mathrm{m}$.

c, d Representative

immunohistochemistry for BrdU in the distal colon of 8-week-old WT and $\mathrm{Bcl}-\mathrm{g}^{-/-}$mice (c). Scale bar: $100 \mu \mathrm{m}$. Quantification of BrdU positive (+) staining for individual mice is shown (d). e, f Representative immunohistochemistry for cleaved Caspase- 3 in the colon of 8-week-old WT and $\mathrm{Bcl-g}-1-$ mice (e). Scale bar: $100 \mu \mathrm{m}$. Quantification of Caspase-3positive $(+)$ staining for individual mice is shown (f). g mRNA expression of the indicated genes from distal colonic tissue of individual ageand gender- matched 8-week-old WT and $\mathrm{Bcl}-\mathrm{g}^{-/-}$mice. $\mathrm{N}=4$ mice per genotype. Data presented are mean \pm SEM
A

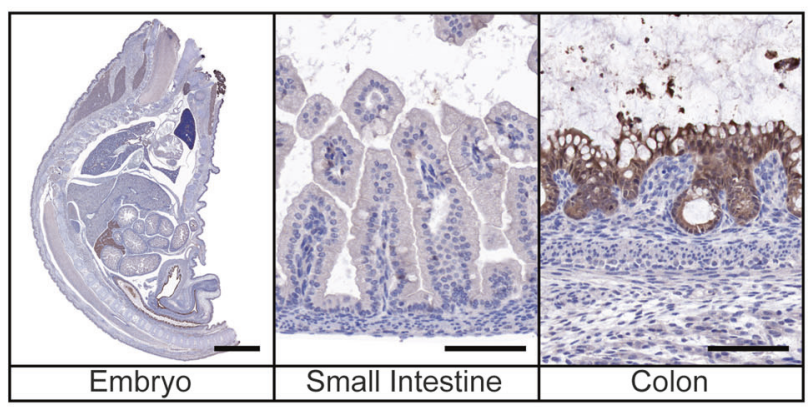

B

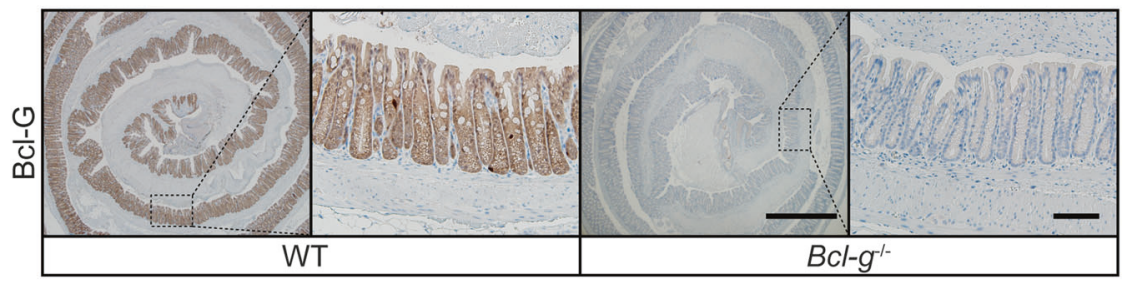

C
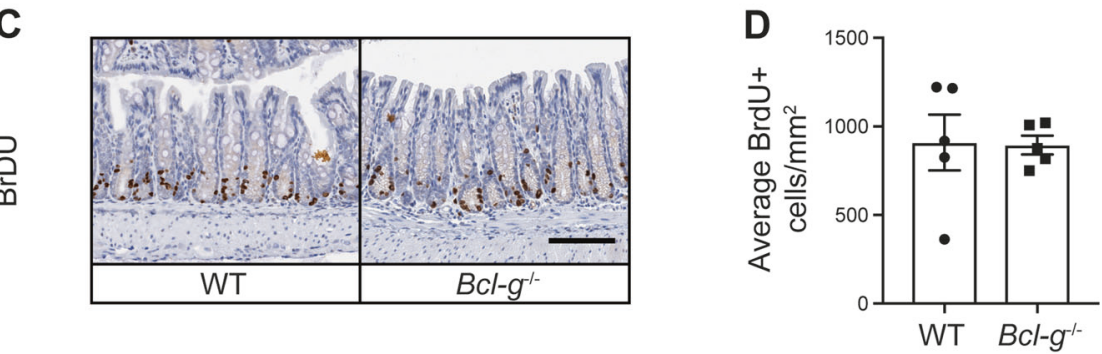

E
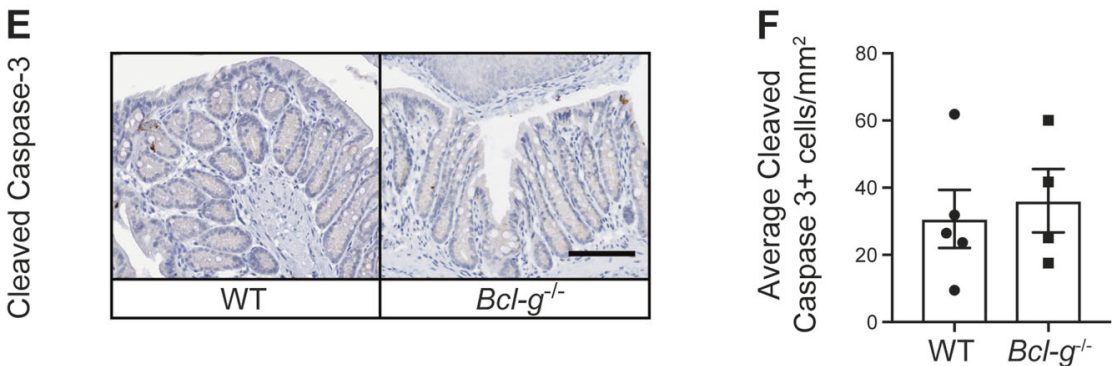

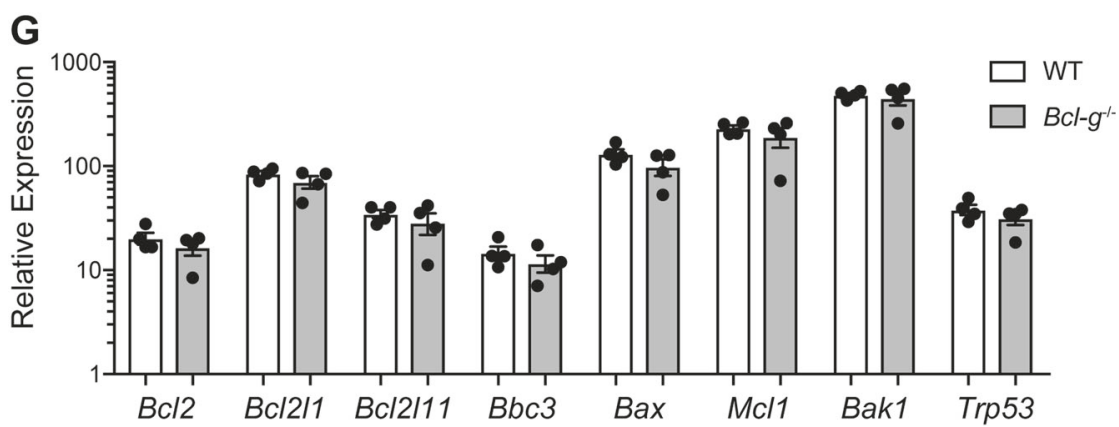

mice to $A p c^{\mathrm{Min} /+}$ mice, which carry a germline truncation in $A p c$ resulting in the development of small intestinal tumors following the spontaneous loss of heterozygosity of the WT $A p c$ allele [17]. $A p c^{\mathrm{Min} /+}$ mice replicate the spontaneous formation of intestinal tumors found in familial adenomatous polyposis (FAP) patients [18]. Interestingly, we observed the lowest expression of Bcl-G in epithelial cells isolated from the distal small intestine (DSI) of naïve WT mice (Fig. 3b), which 
Fig. 2 Loss of Bcl-G accelerates colitis-associated cancer. a Schematic representation of the colitis-associated cancer model with representative colonoscopy images of WT and $\mathrm{Bcl}-\mathrm{g}^{-l-}$ mice at the indicated stage of the model. Images at day 48 and day 72 are shown for the same representative mouse of each genotype. b Colonoscopy scores for individual WT and $\mathrm{Bcl}-\mathrm{g}^{-1-}$ mice at day 48 and day 72 of the model. $N=8$ mice per genotype, $* * * P<0.001$. Student's $t$-test. Representative of $N>3$ experiments. c Total colonic tumor number for individual WT and $\mathrm{Bcl}-\mathrm{g}^{-/-}$ mice on autopsy. $N=8$ mice per genotype, $* * * P<0.001$.

Student's $t$-test. Representative of $N>3$ experiments. d Total colonic tumor area for individual WT and $\mathrm{Bcl}-\mathrm{g}^{-/-}$mice on autopsy. $N=8$ mice per genotype, $* * * P<0.001$. Student's $t$-test. Representative of $N>3$ experiments
A

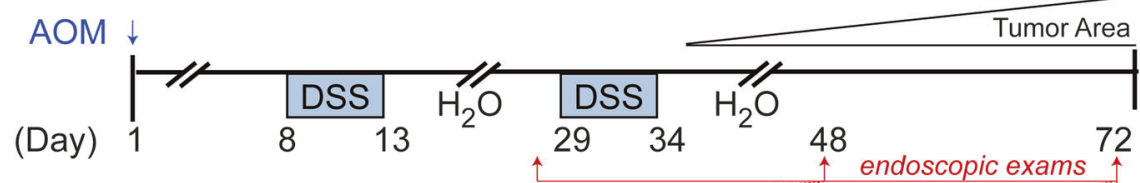

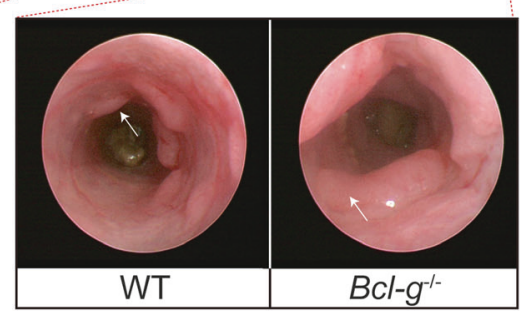

B
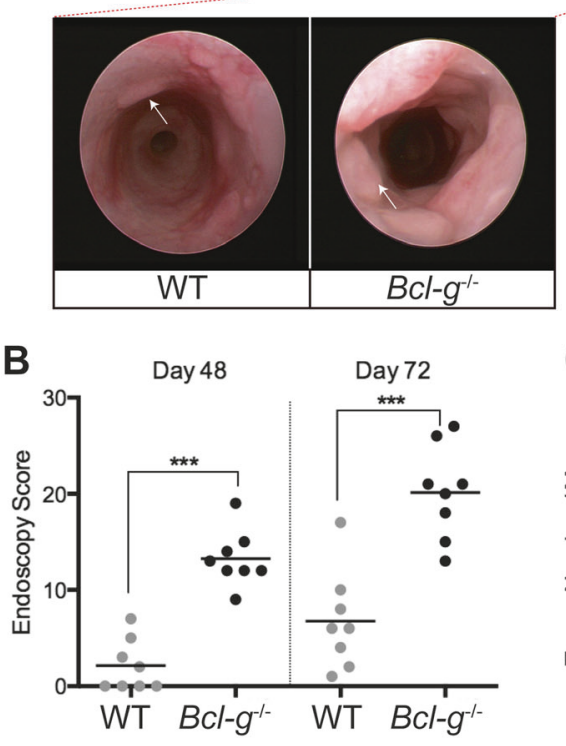

C

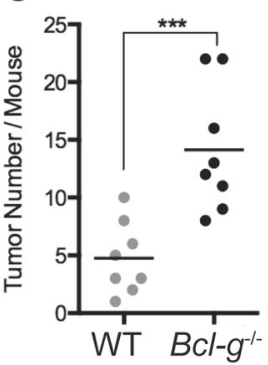

D

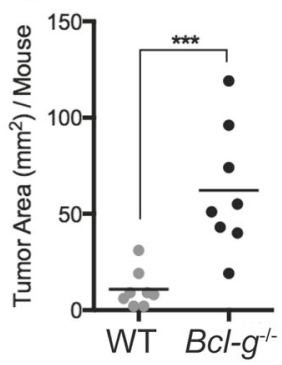

is where the greatest tumor burden in $A p c^{\mathrm{Min} /+}$ mice occurs. However, we did not observe a change in crypt morphology, crypt-villus length, or proliferation in the DSI of $\mathrm{Bcl}_{-} \mathrm{g}^{-1-}$ mice when compared to WT mice (Supplemental Fig. 2a-d), suggesting that loss of Bcl-G does not alter normal GI homeostasis in the DSI. We aged $B c l-g^{-1-} ; A p c^{\mathrm{Min} /+}$ compound mutant mice and littermate $A p c^{\mathrm{Min} /+}$ mice to $\sim 120$ days, a time point when tumors are macroscopically detectable in $\mathrm{Apc}^{\mathrm{Min} /+}$ mice (Fig. 3c). However, we observed no significant difference in the overall number (Fig. 3d) or size of the tumors (Fig. 3e) that were visible in the proximal, middle, or distal small intestine between the genotypes. We also observed no difference in the formation of sporadic tumors in the colon of $B c l-g^{-l-} ; A p c^{\mathrm{Min} /+}$ mice compared to $A p c^{\mathrm{Min} /+}$ mice (Fig. 3d, e). Taken together, these observations suggest that the loss of Bcl-G has no impact on sporadic tumor onset or progression in the small intestine or colon.

\section{Bcl-G does not modulate tumor epithelial proliferation or apoptosis}

In order to begin to understand how Bcl-G may contribute to CAC formation, we compared two of the most well recognized hallmarks of cancer: proliferation and evasion of apoptosis. We found that proliferation, indicated by Ki67positive cells, was comparable between the tumors of WT and $\mathrm{Bcl}_{-} \mathrm{g}^{-/-}$mice that had undergone the CAC model, and in the $A p c^{\mathrm{Min} /+}$ compared to $B c l-g^{-/-} ; A p c^{\mathrm{Min} /+}$ mice (Supplemental Fig. 3a-d). We also observed no significant difference in the number of cells undergoing apoptosis, indicated by cleaved caspase-3-positive staining, in the tumors of $\mathrm{Bcl}_{-\mathrm{g}^{-1-}}$ mice compared to WT mice in either model (Supplemental Fig. 3e-h). Taken together, these observations suggest that Bcl-G does not contribute to the growth rate of tumors irrespective of whether or not they occur in a chronically inflamed environment.

The difference in tumor progression between the two models was not simply a reflection of the inflammation that was induced in the CAC model, since the level of tumorinfiltrating CD45-positive leukocytes was similar between tumors in each of WT and $\mathrm{Bcl}-\mathrm{g}^{-/-}$mice (Supplemental Fig. 4a-d). While there was a significant reduction in CD45+ leukocytes in the $\mathrm{Bcl}-\mathrm{g}^{-1-} ; \mathrm{Apc} \mathrm{Min} /+$ compared to $\mathrm{Apc} \mathrm{Min} /+^{-}$ mice (Supplemental Fig. 4d), this had no impact on the tumor burden. In the acute DSS model, there were no significant changes in weight-loss, colon length or histology (Supplemental Fig. 4e-g). Moreover, FACS characterization of the colonic lamina propria following acute DSS challenge revealed no changes in the influx of T cells or macrophages in Bcl-g ${ }^{-l-}$ mice compared to WT mice (Supplemental Fig. $4 \mathrm{j}-\mathrm{i}$ ). The lack of changes in mucosal inflammation suggests that an epithelial cell-intrinsic change triggered by mucosal damage contributes to the difference in $\mathrm{Bcl}_{-} \mathrm{g}^{-/-}$ mouse tumor burden in the CAC model. 
Fig. 3 Loss of Bcl-g has no impact on the progression of sporadic gastrointestinal tumors. a Representative

immunohistochemistry for Bcl$\mathrm{G}$ in the proximal (PSI), middle (MSI), and distal (DSI) small intestine of 8-week-old WT and Bcl- $g^{-/-}$mice. Scale bar: $50 \mu \mathrm{m}$. b Representative immunoblot analysis of colonic epithelial cells isolated from the PSI, MSI, DSI, and colon of an 8-week-old WT mouse. Representative of $N$ $=3$ mice. $\mathbf{c}$ Schematic representation of tumor progression in the $A p c^{\mathrm{Min}}$ mouse model. d Total PSI, MSI, DSI, and colon $\mathbf{c}$ tumor number for individual age-matched ( 120 days) WT and Bcl-g $\mathrm{g}^{-/-}$ mice on autopsy. $N>11$ mice per genotype. $P$-values are shown. e Total PSI, MSI, DSI, and $\mathrm{C}$ tumor area for individual age-matched ( 120 days) WT and $B c l-g^{-l-}$ mice on autopsy. $N>11$ mice per genotype. $P$ values are shown
A

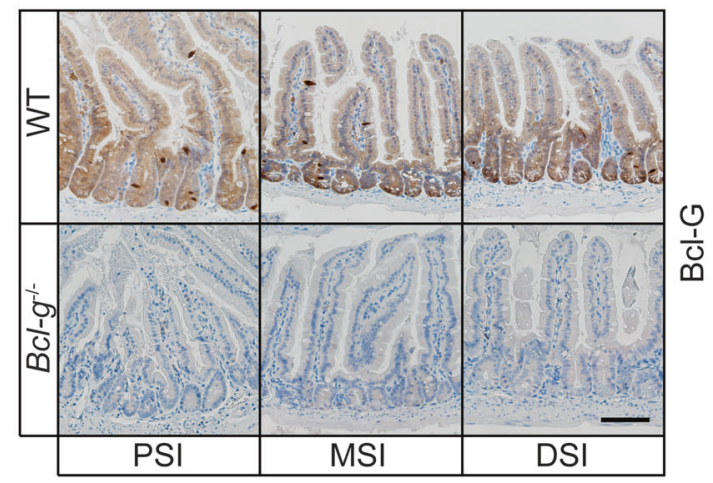

B

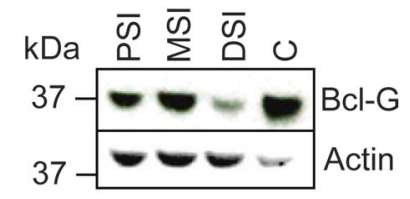

C
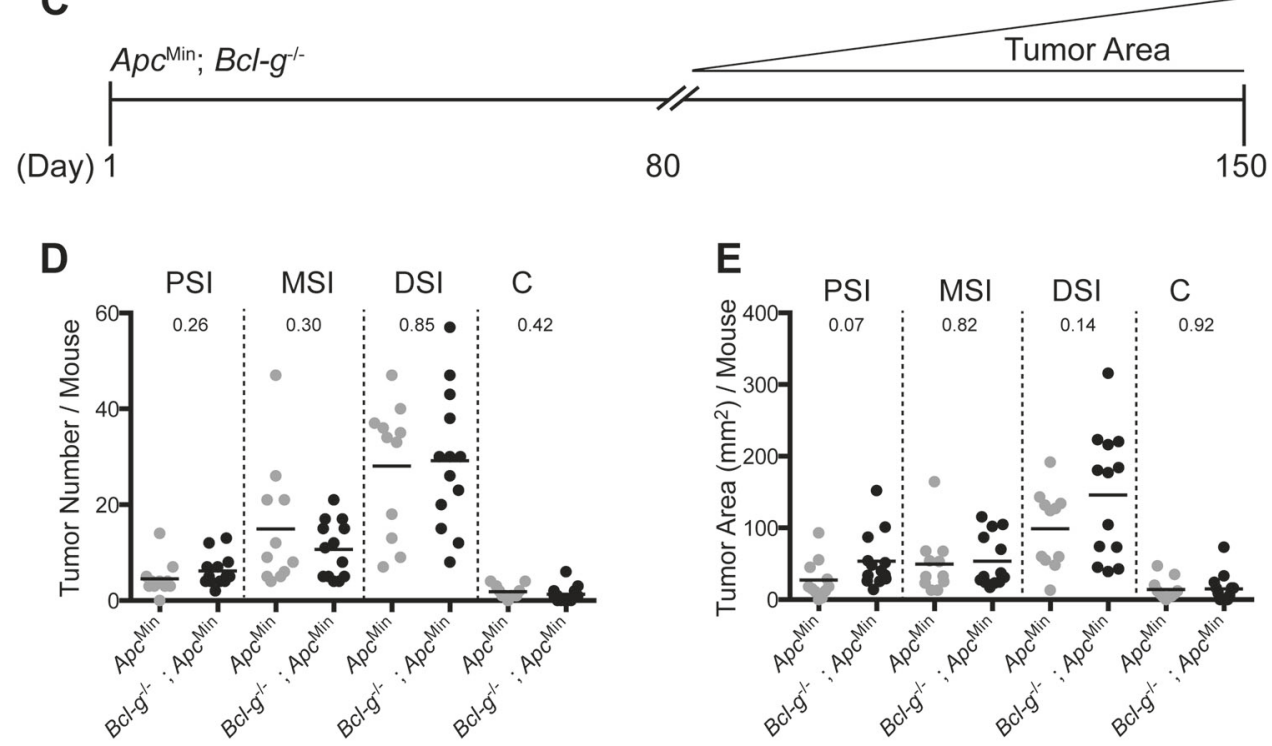

\section{BCL-G expression is decreased in human GI pathologies}

We explored the expression of $B C L-G_{L}$ in human GI pathologies and observed a reduction in $B C L-G$ expression in our own CRC patient cohort, which was specific to late stage tumors (Fig. 4a). We also observed a reduction in $B C L-G$ expression in two publicly available colon cancer data sets (Supplemental Fig. 5a, b). Similarly, we observed a reduction in $B C L-G$ expression in two publicly available data sets for human ulcerative colitis patients [19] (Supplemental Fig. 5c, d). To address the possibility that this reduction in $B C L-G_{L}$ expression was attributed to changes in the proportion of epithelial cells in the inflamed patient tissue, we also examined the expression level of EPCAM, which is expressed exclusively by epithelial cells and found a comparable epithelial content between control and inflamed patients for one dataset (Supplemental Fig. 5e, f). These observations highlight that loss of BCL-G expression is a feature of human GI pathologies.

\section{BCl-G expression is independent of p53 expression in colitis-associated cancer}

p53 expression is a major player in the step-wise genetic sequence associated with colon cancers [20, 21]. In humans, mutations in TP53 that result in loss-of-function are an early event in chronic colitis and dysplasia [22-24]. In contrast, loss of TP53 expression occurs at the advanced stages of sporadic CRC [25]. TP53 has previously been shown to regulate $B C L$ $G$ expression [26], in order to explore this relationship, we screened a panel of six human colon cancer cell lines, with different TP53 profiles (Fig. 4b) for BCLG expression. We observed that in cell lines with mutant TP53 (SW480 and SW620) the expression of $B C L G$ was low, while in cell lines with wild-type TP53 (SKCO-1 and HCT-8) the expression of $B C L G$ was high (Fig. 4c). An exception was LIM1215, which had low wild-type TP53 expression and low BCLG expression. COLO205 has controversial TP53 status, with both wild-type and mutations reported [27]. We observe a dominant wild-type TP53 band by western-blot, and elevated 
Fig. 4 p53 expression does not correlate with Bcl-G expression in murine colonic tumors. a $B C L-G_{L}$ mRNA expression from the non-tumor and adjacent tumor tissue collected from colorectal cancer patients with different stages of tumor progression. $* P<0.05$.

Student's $t$-test. Data are presented relative to GAPDH as mean \pm SEM. b Immunoblot for P53 in the indicated human colorectal cancer cell lines. c $B C L-G_{s}$ and $B C L-G_{L}$ mRNA expression in the colorectal cancer cell lines presented in b. Data for technical triplicates is presented relative to GAPDH. d Representative P53 immunoblot of the normal human colon cell line T4056 after treatment with $10 \mu \mathrm{M}$ Nutlin-3 for 72 h. Representative of technical triplicates from two independent experiments. e $B C L-G_{s}$ and $B C L-G_{L}$ mRNA expression in the normal human colon cell line T4056 presented in d. Data for technical triplicates are presented relative to $G A P D H$. Representative of two independent experiments. $* P<0.05$. Student's $t$-test. f Representative p53 staining and Bcl-G staining in WT CAC tumors. Scale bar: $100 \mu \mathrm{m}$. g Representative p53 staining (arrows) and Bcl-G staining in $A p c^{\text {Min }}$ DSI tumors. Scale bar: $100 \mu \mathrm{m}$
A

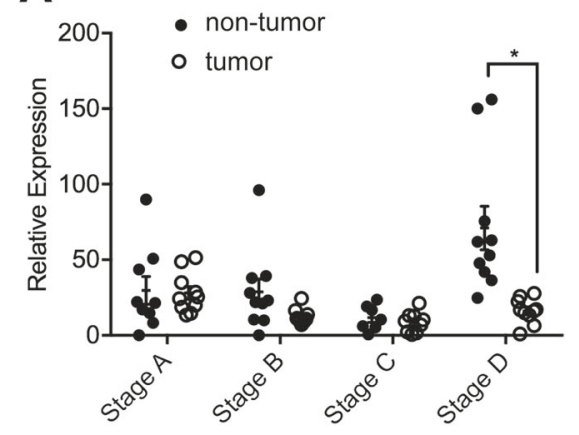

B
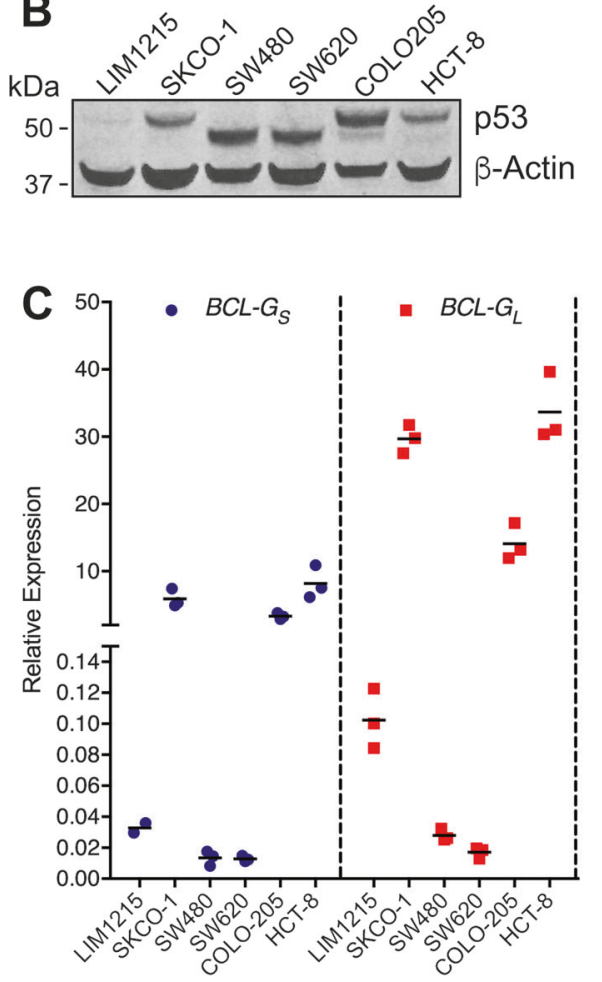
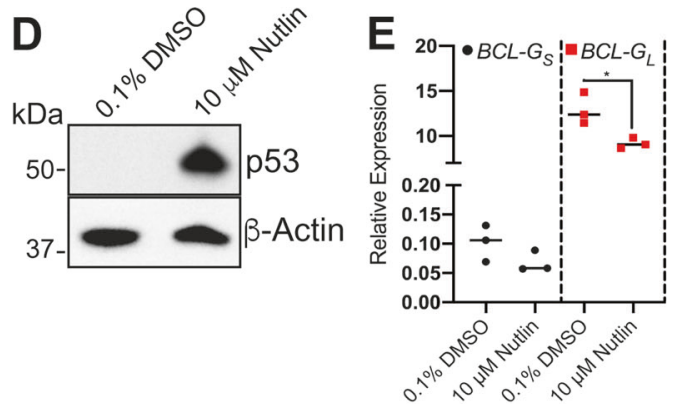

$\mathbf{F}$
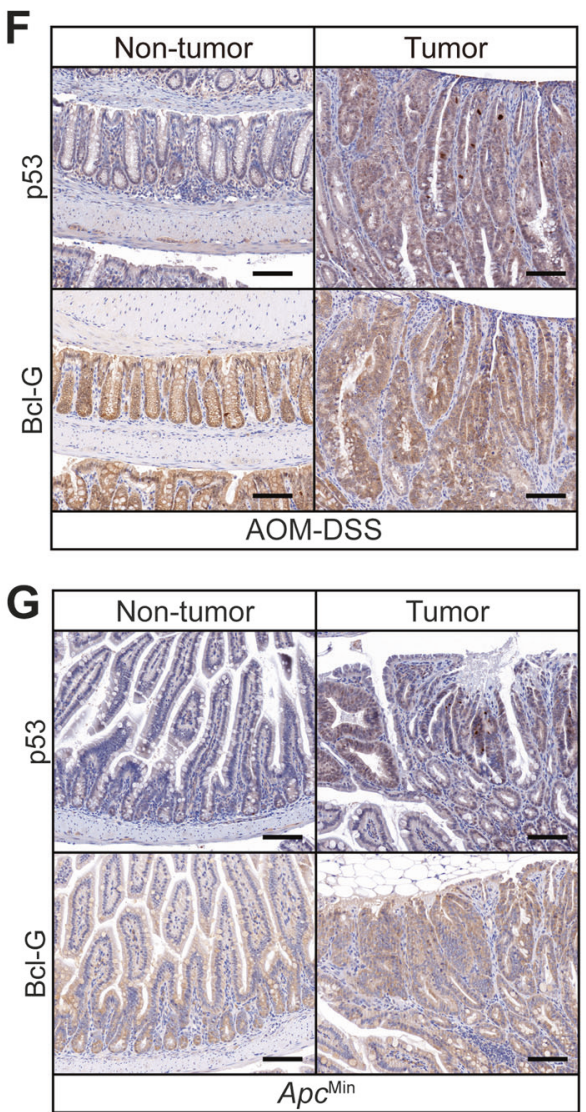

$B C L G$ expression (Fig. 4b, c). In order to further explore a potential relationship between TP53 and BCLG expression, we stimulated the normal human colon cell line T4056 with $10 \mu \mathrm{M}$ of Nutlin-3 for $72 \mathrm{~h}$ to induce TP53 expression (Fig. 4d). Compared to the vehicle control we observed no changes in BCLG $_{S}$ expression following treatment with Nutlin-3, while BCLG ${ }_{L}$ was mildly decreased (Fig. 4e). In the $\mathrm{Bcl}-\mathrm{g}^{-1-}$ mice, which mimic loss of $\mathrm{BCLG}_{\mathrm{L}}$, we detected no relationship between the expression of p53 and Bcl-G in the tumors of either of our colon cancer models (Fig. 4f, g).

\section{Bcl-G is expressed by LGR5 + colonic stem cells}

Colon cancer arises from a highly proliferative epithelium that is continuously renewed under steady-state conditions.
Following epithelial injury in the colon, the homeostatic renewal process is replaced by a regenerative response [28], with highly active regenerative responses known to contribute to the formation of CRC tumors [29]. Since DSS-associated injury induces a mucosal wound healing response, we next sought to functionally test if there was a potential role for $\mathrm{Bcl}-\mathrm{G}$ in the regeneration response, which is initiated by Lgr5 + stem cell populations [30]. To this end, we first established that $\mathrm{Bcl}-\mathrm{g}$ was expressed by Lgr5 + cells, following FACS isolation of $\mathrm{GFP}^{+}$cells from the colon of Lgr5-EGFP-IRES-CreERT [2] mice [30] (Supplemental Fig. 6a, b). We next tested a role for Bcl-G in the self-renewal process by generating organoids from the colon and small intestine of littermate WT and $\mathrm{Bcl}-\mathrm{g}^{-1-}$ mice (Fig. 5a). We observed no difference in the 
Fig. 5 Loss of BclG does not alter regenerative potential of colonic epithelial cells. a Representative images of small intestine (day 7) and colonic (day 5) organoids generated from WT and $B c l-g^{-l-}$ mice. Scale bar: $100 \mu \mathrm{m}$. b, c Quantification of the proportion of organoids formed from single cell suspension (b), and the number of spheroids and organoids formed (c) in the small intestine or colon of WT and $B c l-g^{-1-}$ mice. $* * * P<$ 0.001 . Student's $t$-test. Data are presented as mean \pm SEM
A

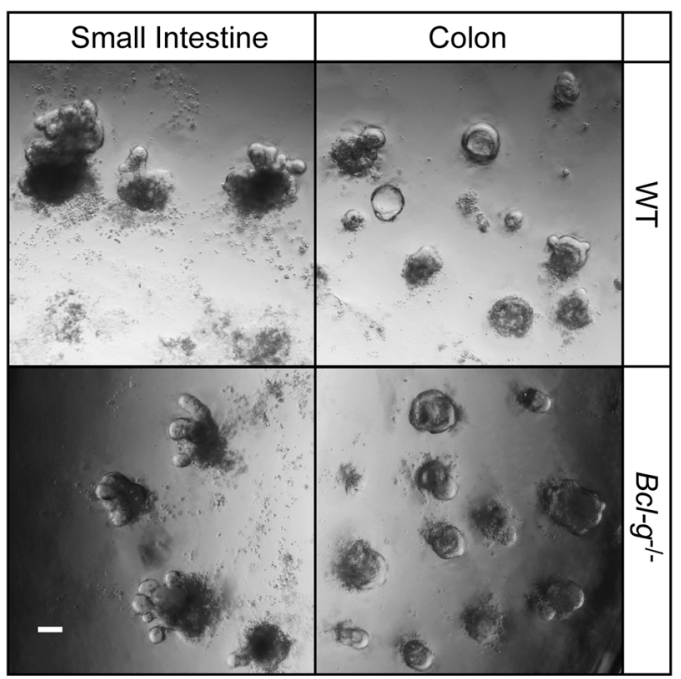

B
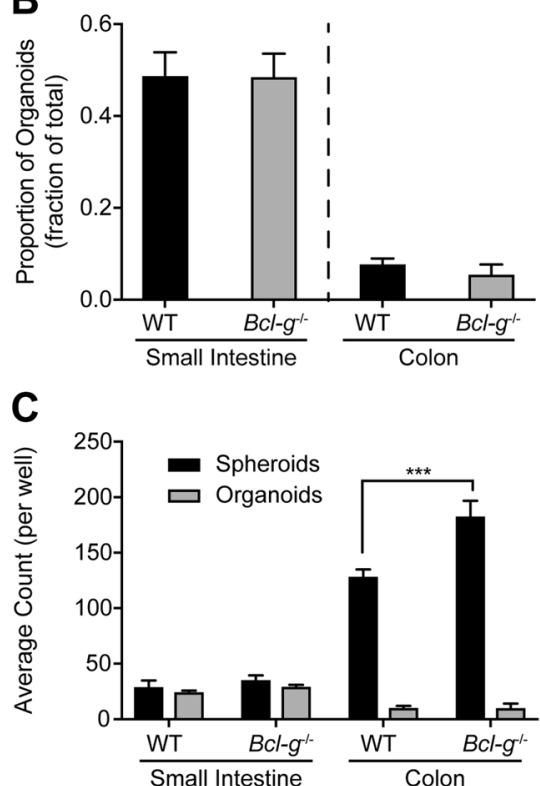

proportion of organoids that were derived from either genotype (Fig. 5b), consistent with our observation that there was no change in proliferation of epithelial cells within the GI tract (Supplemental Fig. 3). We observed a significant increase in the ability of $\mathrm{Bcl}_{-} \mathrm{g}^{-/-}$cells to generate spheroids (Fig. 5c), also referred to as colonospheres, which can be composed of several types of colonic epithelial cells. In contrast, we did not observe a change in the number of organoids, defined as multilobulated structures with a pseudolumen. Organoids develop from a spheroid by forming one or more buds (multicellular protrusions), and are also referred to as a colonoid. The increased number of spheroids, without a corresponding increase in organoids, suggests changes in the behavior of epithelial cells.

To further explore the role of Bcl-G in a regenerative response, we lethally irradiated WT mice (Fig. 6a) and compared the expression of p53, Puma as an indicator of cell death, and $\mathrm{Bcl}-\mathrm{g}$ in the epithelium of the small intestine as the most radio-sensitive compartment, which is routinely examined to assess the regenerative capacity following irradiation-induced epithelial cell death [31, 32]. Over the course of the regenerative response we found no correlation between any of the genes examined (Fig. 6b-d), further highlighting that $\mathrm{Bcl}-\mathrm{g}$ expression is not associated with $p 53$. On further comparison of irradiation-induced epithelial damage at $12 \mathrm{~h}$, the peak of epithelial cell death, there was no visible histological difference between WT and $\mathrm{Bcl}-\mathrm{g}^{-1-}$ mice (not shown) consistent with the lack of change in p53 or Puma expression (Fig. 6e). Taken together, Bcl-G does not appear to contribute to epithelial cell survival.

\section{Loss of Bcl-G alters the colon mucin scaffolding network}

In order to examine how the epithelial response to DSS may promote tumor formation in the absence of Bcl-G expression, we employed a model of chronic colitis that most closely recapitulates the distal colonic mucosal damage associated with ulcerative colitis [33]. Mice were provided with three cycles of $2 \%$ DSS in their drinking water to mimic the recurring flares of mucosal damage experienced by IBD patients (Fig. 7a). No appreciable change in daily weights, colitis scores or colon lengths were observed (Supplemental Fig. 7). On Day 61 of this model, colonic epithelial cells were isolated and whole cell lysates were prepared for quantitative mass spectrometry (MS) analysis to identify global changes in the proteome compared to naïve, unchallenged mice at steady-state. While we observed a number of changes between naïve WT and $\mathrm{Bcl}_{-} \mathrm{g}^{-1-}$ mice including Bcl-G (Fig. 7b), as expected, we were most intrigued by the changes observed in mucins, and mucin-like proteins. Mucins are heavily Oglycosylated cell surface proteins that are a first line of defense in protecting the epithelial cells that line the GI tract [34]. Muc1 is known to be the predominant cell surface mucin in the stomach, while Muc2, Muc4, Muc12, and Muc13 are the primary cell surface mucins found in the intestine [35]. We detected reduced levels of Muc13 (1.10 $\mathrm{Log}_{2}$ fold) in naive $\mathrm{Bcl}-\mathrm{g}^{-1-}$ mice compared with WT mice (Fig. 7b), although this was not observed at the gene level (Fig. 7d).

Fc-gamma binding protein (Fcgbp) is covalently attached to Muc2 to provide structural integrity to the 
Fig. 6 Loss of Bcl-G does not alter irradiation-induced damage in the intestine. a Schematic representation of the irradiation model used to study intestinal damage. Mice were lethally irradiated and collected at the indicated time points. b-d mRNA expression of p53 (b), Puma (c), and Bclg (d) in WT mice at the indicated time points post-irradiation. $N=3$ mice per time point. Data presented as mean \pm SEM, relative to Gapdh. e, $\mathbf{f}$ mRNA expression of $p 53$ (e) and Puma (f) in WT and $\mathrm{Bcl}-\mathrm{g}^{-1-}$ mice that were untreated and $12 \mathrm{~h}$ postirradiation. $N=2-3$ mice per time point. Data presented as mean $\pm \mathrm{SEM}$, relative to Gapdh.
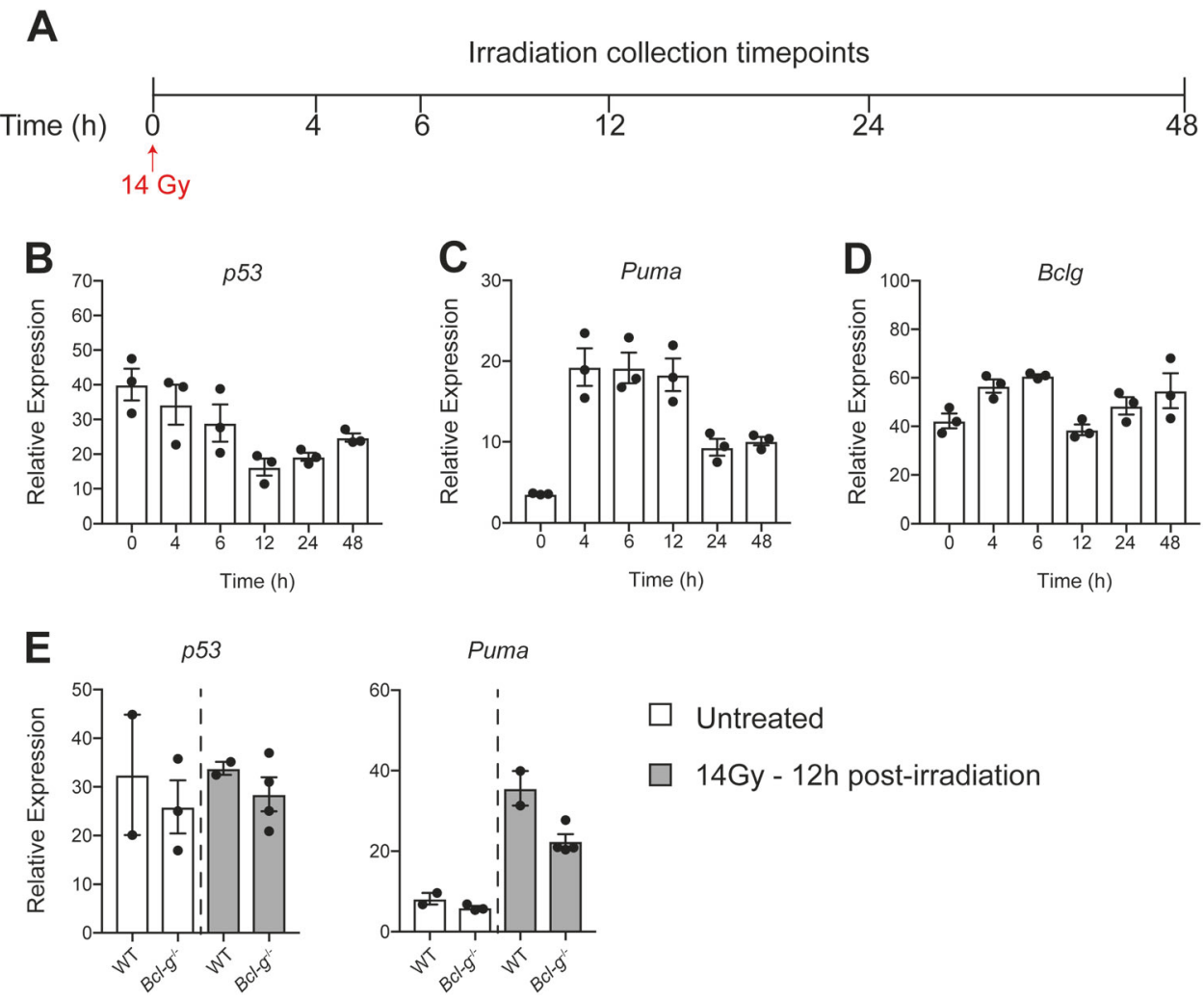

Untreated

14Gy - 12h post-irradiation mucus network, with recent proteomic analyses demonstrating that both proteins are expressed in the mucus granule of goblet cells found in the human colon [36]. We identified a significant reduction in the expression of Fcgbp in the $\mathrm{Bcl}-\mathrm{g}^{-l-}$ mice compared with WT mice in both naïve mice (1.09 $\log _{2}$ fold) and following DSS treatment (1.01 $\log _{2}$ fold; Fig. 7b, c). We confirmed this observation at the expression level of the corresponding genes in DSS-treated epithelial cells (Fig. 7d). Chloride accessory channel 1 (Clca1), which has a similar expression pattern to Muc2 [37], was also significantly decreased in naïve $\mathrm{Bcl}-\mathrm{g}^{-1-}$ mice (1.32 $\log _{2}$ fold) and following DSS treatment (2.04 $\log _{2}$ fold; Fig. $7 b$, c). In addition, we identified a significant reduction in the levels of Mucosal Pentraxin 1 (Mptx1) in Bcl-g $\mathrm{g}^{-/-}$mice following chronic DSS-induced mucosal damage (Fig. 7c), which was also reduced at the gene level (Fig. 7d). Mptx1 is a colon-specific marker for mucosal cell integrity that is highly expressed in a naïve colon, and strongly reduced upon epithelial damage [38], suggesting increased epithelial damage in $\mathrm{Bcl}^{-g^{-l-}}$ mice, which was reflected by histopathology in the $\mathrm{Bcl}-\mathrm{g}^{-1-}$ mice (Fig. 7e).

Collectively these data suggest that there are several changes that occur in the mucus scaffold within naïve $\mathrm{Bcl}-\mathrm{g}^{-/-}$ mice that are also present following chronic DSS treatment, consistent with previous reports implicating changes to mucins in CRC.

\section{Discussion}

$\mathrm{Bcl}-\mathrm{G}$ is a poorly characterized member of the Bcl-2 family of proteins. The alternative splice acceptor site that is used to produce $B C L-G_{s}$ is not conserved across other species, for this reason we utilized mouse Bcl-G, as the closest homolog to understand the biological function of human $B C L-G_{L}$. We have demonstrated that mouse Bcl-G is highly expressed in the epithelial cells lining the crypt-villus structures of the small intestine and colon throughout development. The lack of a compensatory increase in other classic Bcl-2 family members in the adult colon when Bcl$\mathrm{G}$ was genetically deleted suggests that the function of Bcl$\mathrm{G}$ is unlikely to be shared by the other family members. This is consistent with the non-redundant roles for the various Bcl-2 family members in numerous other disease models [39-42].

The only overt functional phenotype in the colon reported for a Bcl-2 family member has been for Puma and Bcl- $\mathrm{x}_{\mathrm{L}}$, with the genetic loss of Puma associated with reduced cell death and resistance to the clinical symptoms of DSS-induced colitis [43]. Puma ${ }^{-1-}$ mice have an increased tumor burden in the CAC model, and when crossed into the $A p c^{\mathrm{Min}}$ background [44]. Specific ablation of Bcl- $x_{L}$ in the intestinal epithelium does not result in an overt phenotype; however, tumor burden is significantly reduced in the CAC model and associated with increased 


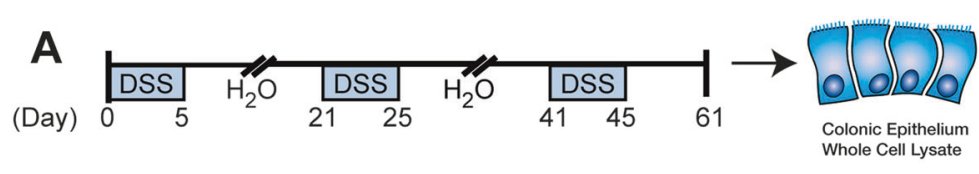

B

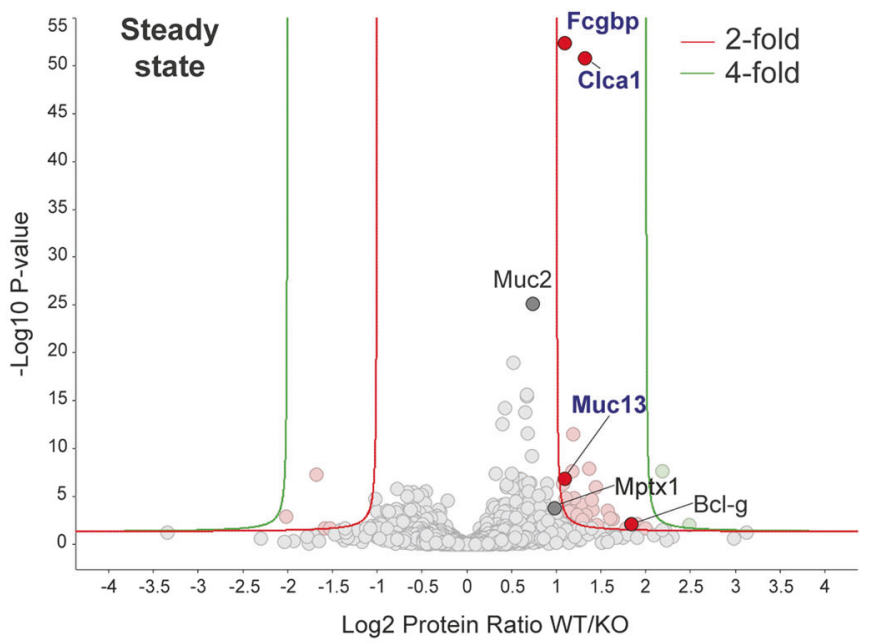

C

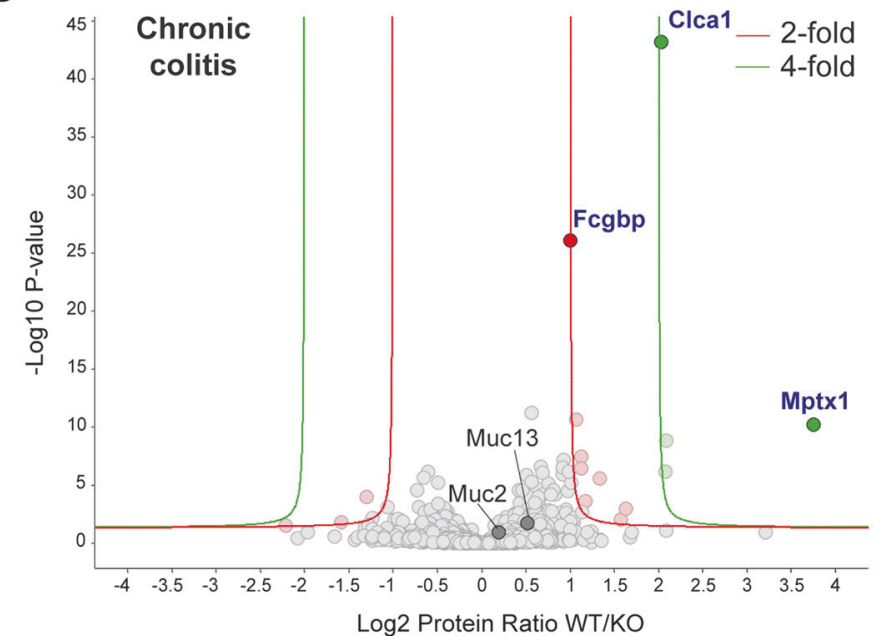

D

Clca1
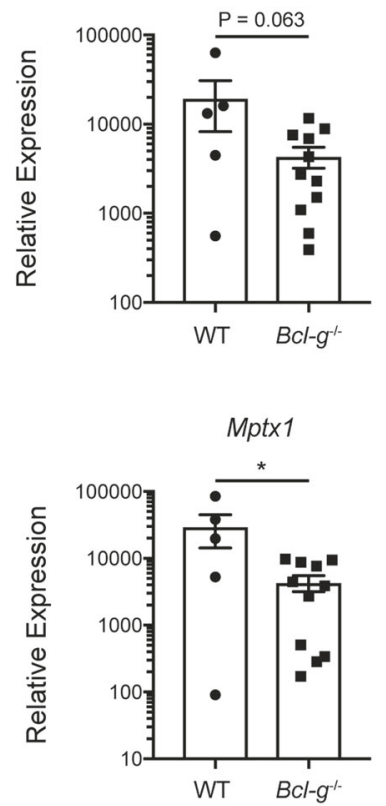

Muc13

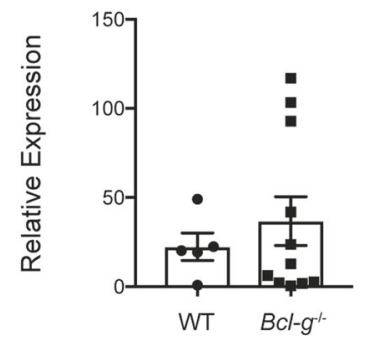

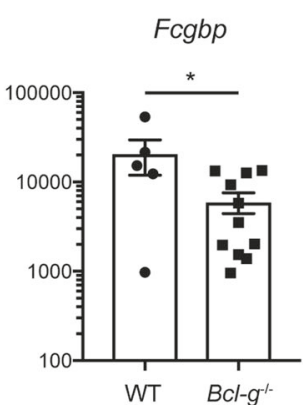

Muc2

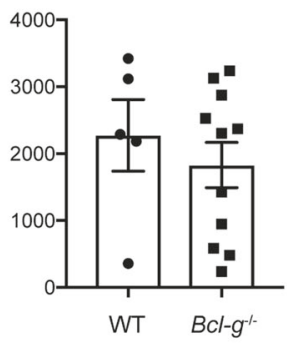

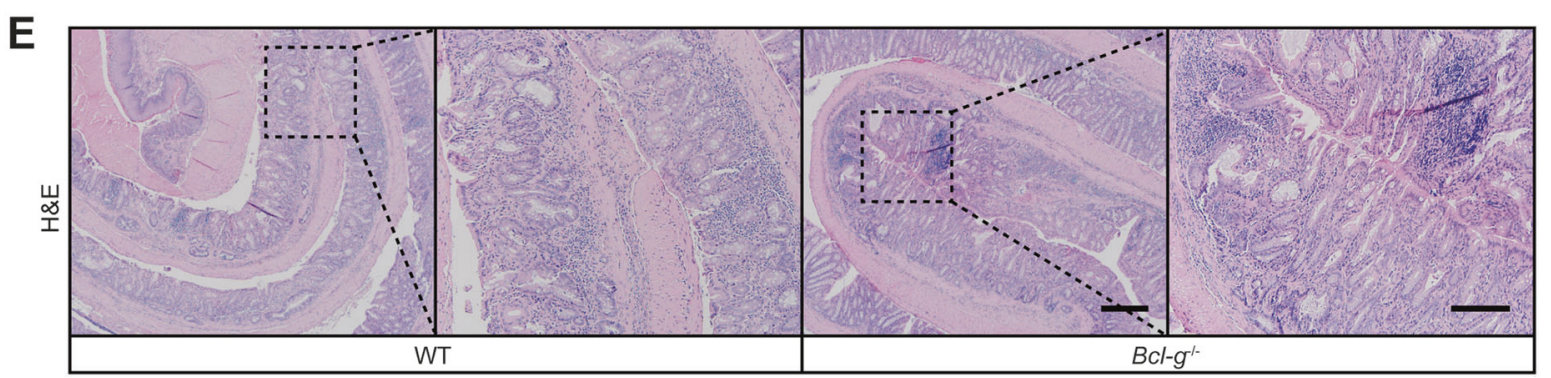

cell death [45]. By contrast, and consistent with our observations for Bcl-G, deficiency in Bad, Bim, Bax, Bak, or Noxa had no effect on epithelial apoptosis following acute DSS-induced colitis [43]. Bid, on the other hand, has been shown to have a non-apoptotic function during intestinal inflammation, with selective ablation of Bid in intestinal epithelial cells or macrophages resulting in a dampening of cytokine secretion and chemically induced colitis [46]. We have, however, demonstrated a unique sensitivity of $\mathrm{Bcl}-\mathrm{g}^{-/-}$mice to the CAC model.

The balance between homeostasis and the support of cancer progression is not well explored in vivo. Much of 
Fig. 7 Loss of Bcl-g is associated with an altered mucin network. a Schematic representation of the chronic colitis model and workflow. b Volcano plot illustrating the $\log _{2}$ protein ratios in whole cell lysates of colonic epithelial cells isolated from naïve WT relative to littermate $B c l-g^{-/-}$mice following quantitative MS analysis. Proteins were deemed differentially regulated if the $\log _{2}$ fold change in protein expression was greater than 2-fold (red) or 4-fold (green) and a $-\log _{10}$ $p$-value (with Benjamini-Hochberg correction) $\geq 1.3$, equivalent to a $p$ value $\leq 0.05$. c Volcano plot illustrating the $\log _{2}$ protein ratios in whole cell lysates from colonic epithelial cells isolated from chronic DSStreated WT relative to littermate $\mathrm{Bcl}-\mathrm{g}^{-l-}$ mice following quantitative MS analysis. Proteins were deemed differentially regulated in the $\log _{2}$ fold change in protein expression was greater than 2-fold (red) or 4fold (green) and a $-\log _{10} p$-value (with Benjamini-Hochberg correction) $\geq 1.3$, equivalent to a $p$-value $\leq 0.05$. d mRNA expression of mucus-associated genes Clcal, Fcgbp, Mptxl, Muc2, and Muc13 in WT and $\mathrm{Bcl}-\mathrm{g}^{-1-}$ mice following chronic colitis. $N \geq 5$ mice per genotype. $* P<0.05$. Student's $t$-test. Data presented as mean \pm SEM, relative to Gapdh. e Representative H\&E sections of the distal colon from mice of the indicated genotype on day 61 of the model. Scale bar: $200 \mu \mathrm{m}$, inset: $100 \mu \mathrm{m}$

our knowledge is centered around the tumor suppressor gene p53, as a central factor for cell fate decisions and prevention of the expansion of damaged and mutated cells [47]. The activation of p53 in response to DNA damage or cellular stress leads to cell cycle arrest, apoptosis or senescence depending on the cellular context [48], with the loss of p53 in colonic epithelial cells known to increase their survival by reinstating protective factors that control inflammation leading to an increase in CAC incidence and dysplasia [49-51]. Previous studies have linked BCL-G and p53 expression, with suggestions that RNAi knockdown of $B C L-G$ resulted in a significant reduction in p53 induced apoptosis, but not a complete ablation [48]. However, we did not observe a significant relationship between Bcl-G and p53 in the mouse colonic epithelium, in contrast to the observation that p53 can regulate $B C L-G$ expression [26]. The discrepancies in our murine models may lie in the potential for different functions for BCL-Gs compared to BCL- $\mathrm{G}_{\mathrm{L}}$, with previous publications not clearly indicating the BCL-G isoform examined.

Our quantitative proteomics analysis suggested that loss of Bcl-G results in the modulation of the mucin network, including Muc2 for example, which is the main gel-forming mucin secreted by goblet cells $[52,53]$, creating a physical barrier that protects the underlying epithelium. The question remains as to how Bcl-G regulates mucin levels. We do not attribute this observation to increased cell death in $\mathrm{Bcl}-\mathrm{g}^{-1-}$ mice, resulting in lower levels of mucin producing cells, as we observed no changes in the length of the crypt-villus axis or the number of Caspase-3-positive cells at steadystate or in the cancer models. We believe that the contribution of Bcl-G to the mucin network is a reflection of a potential difference in the transition from proliferation to differentiation of colonic epithelial cells. While we observed no significant differences in $\mathrm{Ki} 67+$ proliferating cells in any of our models, loss of $\mathrm{Bcl}-\mathrm{g}$ was linked to decreased Clcal, which is also decreased in CRC patients and is associated with inhibition of CRC epithelial differentiation when knocked down in cell lines [37, 54]. Similar to $\mathrm{Bcl}-\mathrm{g}^{-I-}$ mice, $\mathrm{Clcal}^{-1-}$ mice display no overt phenotype in the acute DSS model, although mucous composition is not associated specifically with Clca1 expression [37, 54]. Alternatively, changes in the mucin network in $\mathrm{Bcl}-\mathrm{g}^{-/-}$ mice may reflect changes in goblet cell restitution, a process that is not well understood.

The genetic loss of $M u c 2$ results in a depleted mucus layer and elevated levels of the pro-inflammatory cytokines TNF- $\alpha$, IL-1 $\beta$, and IFN- $\gamma$ [55-57]. The expression of $B C L-$ $G_{L}$ has also been shown to be enhanced by both IFN- $\alpha$ and IFN- $\gamma$ stimulation, through the ability of STAT1 and IRF-1 to interact with the BCL-G promoter [58]. We were also intrigued with the decrease in Muc13 expression that was observed in naïve $\mathrm{Bcl}-\mathrm{g}^{-/-}$mice, since increased expression of Muc13 has been detected in ovarian, gastric, and metastatic colon cancers [59-62]. In mouse models, Muc13 protects against intestinal epithelial damage and inflammation induced by DSS by protecting colonic epithelial cells from cell death through the activation of both intrinsic and extrinsic NF- $\mathrm{BB}$ signaling and subsequent upregulation of $\mathrm{BCL}_{\mathrm{L}}$ [63]. Loss of Muc13 may represent a compensatory mechanism to maintain homeostasis in the absence of Bcl-G. In summary, we have demonstrated that the Bcl- $\mathrm{g}^{-/-}$mice harbor a disrupted mucin network and thus are predisposed to colon tumorigenesis.

\section{Materials and methods}

\section{Mice}

All animal procedures were approved and conducted in accordance with guidelines established by the Walter and Eliza Hall Institute of Medical Research Animal Ethics Committee. Wild-type (WT) and littermate $\mathrm{Bcl}-\mathrm{g}^{-/-}$mice [9] on a C57BL/6 background were generated by heterozygote crosses $\left(B c l-g^{+-}\right)$, as were $A p c^{\text {Min }}$ [17] and littermate $A p c^{\mathrm{Min}}: B c l-g^{-l-}$ mice, and heterozygous Lgr5-EGFP-IREScreERT2 mice [30]. All mice were maintained under specific pathogen-free conditions at the Walter and Eliza Hall Institute for Medical Research. Two hours prior to euthanasia, mice received an intraperitoneal (i.p.) injection of Bromodeoxyuridine (BrdU, $50 \mathrm{mg} / \mathrm{kg}$; Sigma-Aldrich, RPN201).

\section{Induction of mucosal damage}

Acute mucosal damage was induced in gender and agematched littermate mice by providing $1.5 \%(w / v)$ DSS 
dextran sulfate sodium (DSS; 36-50 kDa, MP Biomedicals, 0216110) ad libitum in the drinking water for 5 days followed by 3 days of normal drinking water. Chronic mucosal damage was induced in littermate gender- and age-matched mice by providing $2 \%(\mathrm{w} / \mathrm{v})$ dextran sulfate sodium ad libitum in the drinking water for 5 days, followed by 16 days of normal drinking water, a cycle that was repeated three times. Colitis-associated cancer (CAC) was induced by providing azoxymethane (AOM; $10 \mathrm{mg} /$ kg; Sigma-Aldrich, A5486) by i.p. injection 7 days prior to the chronic mucosal damage model (1.5\% w/v DSS). Routine colonoscopy was performed and tumor burden scores were generated using a standard scoring system [33].

\section{Irradiation}

To study epithelial regeneration, gender- and age-matched mice were exposed to a single dose of $14 \mathrm{~Gy}$ gamma radiation from a cobalt-60 source. After ethical euthanasia, the small intestine was removed and epithelial cells isolated following digestion in $3 \mathrm{mM}$ EDTA for $1 \mathrm{~h}$ at room temperature. Following gentle shaking, the detached epithelial cells were separated by centrifugation and the epithelial pellet was processed for subsequent analysis.

\section{Induction of TP53}

Cell lines were cultured to confluency in six-well plates, and left either treated with $0.1 \%$ DMSO (vehicle) or Nutlin-3 (10 $\mu$ M, Cayman Chemicals Cat\#18585) for $72 \mathrm{~h}$. Cells were harvested, and prepared for Immunoblot or Real-time PCR analysis.

\section{Human subjects}

Data from two NCBI GEO [64] human ulcerative colitis studies were downloaded and analyzed by GraphPad Prism. The following studies were used: GSE9452 (five control, 13 non-inflamed, and eight inflamed ulcerative colitis samples) [19] and GSE65114 (12 normal and 16 ulcerative colitis samples). Normalized expression levels for $B C L-G_{L}$ and EPCAM were examined and pairwise Student's $t$-test conducted to determine significant difference between groups $(P<0.05)$.

Gene expression data from RNA microarray analysis of tumor and non-tumor tissues from colorectal cancer patients were obtained through the publicly available 'Oncomine Gene Browser' database (ThermoFisher Scientific).

For gene expression data generated on our CRC patient cohort, all human tissues were obtained with informed patient consent and analyzed in accordance with approvals from the ethics committee at the Walter and Eliza Hall Institute of
Medical Research. Tumor and adjacent normal (non-cancerous) tissues were analyzed from the same patient.

\section{Histological analysis}

The excised colon from each mouse was opened longitudinally, "swiss rolled", and fixed for $24 \mathrm{~h}$ in $10 \%(\mathrm{w} / \mathrm{v})$ buffered formalin at room temperature. All tissues were embedded in paraffin, and 5- $\mu \mathrm{m}$ thick sections were stained with Haematoxylin and Eosin (H\&E). Unstained sections were deparaffinised in xylene and rehydrated in a graded series of ethanol (100-70\% v/v) finishing in $\mathrm{dH}_{2} \mathrm{O}$. Antigen retrieval was achieved by boiling slides in citrate buffer (ThermoFisher Scientific, AP-9003-500) or EDTA-Tris (1 mM EDTA, $10 \mathrm{mM}$ Tris pH 9) for $15 \mathrm{~min}$, followed by incubation in $3 \%(\mathrm{v} / \mathrm{v}) \mathrm{H}_{2} \mathrm{O}_{2}$ to inhibit endogenous peroxidases. Sections were blocked in $5 \%(\mathrm{v} / \mathrm{v})$ goat serum and incubated with primary antibodies against Bcl-G (clone 2E11, [9]), BrdU (BD Biosciences, BD555627), Ki67 (Cell Signaling, CST 9129), Caspase-3 (Cell Signaling, CST 9664), CD45 (BD Biosciences, BD553076), or p53 (Leica Biosystems, P53-CM5P-L) overnight at $4{ }^{\circ} \mathrm{C}$ in a humidified chamber. Sections were rinsed, then incubated in HRPconjugated biotinylated secondary antibodies for $1 \mathrm{~h}$ at room temperature, after which HRP (Vector Laboratories) was detected using a DAB Peroxidase kit (Dako, K3468112). All sections were counterstained with Haematoxylin. The extent of positive staining per mm [2] of tissue was quantified using ImageJ software.

\section{Immunoblotting}

Colonic tissue was lysed for 30 min in RIPA buffer containing $1 \mathrm{mM}$ vanadate, protease, and phosphatase inhibitors. Proteins were separated on $4-12 \%$ Tris-glycine gradient gels (ThermoFisher Scientific, NP0321BOX) and transferred to nitrocellulose. After blocking in Odyssey buffer (LI-COR Biosciences, 927-40000), membranes were incubated in primary antibodies directed against Bcl-G (clone 2E11), p53 (Leica Biosystems), or Actin (Sigma, A2066, A4700) overnight at $4{ }^{\circ} \mathrm{C}$, followed by the appropriate secondary antibody for $1 \mathrm{~h}$ at room temperature (LICOR Biosciences, 926-32221, 926-68072, 926-68076). Proteins were visualized using the Odyssey infrared imaging system (LI-COR Biosciences).

\section{Quantitative proteomics analysis}

Littermate age- and gender-matched mice were subjected to the chronic mucosal damage model or left untreated and isolated epithelial cells were prepared for protein lysis. Briefly, epithelial cells were isolated following digestion in $3 \mathrm{mM}$ EDTA for $1 \mathrm{~h}$ at room temperature followed by lysis 
in TX-100 buffer. Protein concentrations of lysates were determined by the BCA method (ThermoFisher Scientific, $23225)$ prior to performing global proteome analysis.

Whole cell lysates $(200 \mu \mathrm{g})$ derived from each biological replicate were prepared for mass spectrometry analysis using the FASP digestion method as previously described [65], with the following modifications. Proteins were reduced with Tris-(2-carboxyethyl)phosphine (TCEP; 10 $\mathrm{mM}$ final concentration, ThermoFisher Scientific, 20490), digested with sequence-grade modified Trypsin Gold (Promega, V5280) ( $1 \mu \mathrm{g}$ for WCLs) in $50 \mathrm{mM} \mathrm{NH} \mathrm{NCO}_{3}$ and incubated overnight at $37^{\circ} \mathrm{C}$. Peptides were then eluted with $50 \mathrm{mM} \mathrm{NH}_{4} \mathrm{HCO}_{3}$ in two $40 \mu \mathrm{L}$ sequential washes and acidified in $1 \%$ formic acid (final concentration).

MS analysis was performed as described previously [66]. Briefly, acidified peptide mixtures $(1 \mu \mathrm{l})$ were subjected to nano-LC MS/MS analysis on a nanoAcquity system (Waters), coupled to a Q-Exactive Classic mass spectrometer. Raw files consisting of high-resolution MS/ MS spectra were processed with MaxQuant (version 1.5.8.3) for feature detection and protein identification using the Andromeda search engine [67]. Extracted peak lists were searched against the UniProtKB/Swiss-Prot Mus musculus database (October 2016) and a separate reverse decoy database to empirically assess the false discovery rate (FDR) using strict trypsin specificity allowing up to two missed cleavages. The minimum required peptide length was set to seven amino acids. Modifications: Carbamidomethylation of Cys was set as a fixed modification, while $\mathrm{N}$-acetylation of proteins and oxidation of Met were set as variable modifications. The mass tolerance for precursor ions and fragment ions were $20 \mathrm{ppm}$ and $0.5 \mathrm{Da}$, respectively. The "match between runs" option in MaxQuant was used to transfer identifications made between runs on the basis of matching precursors with high mass accuracy [68]. PSM and protein identifications were filtered using a target-decoy approach at a false discovery rate (FDR) of $1 \%$. Statisticallyrelevant protein expression changes between the WT and Bcl- $g^{-/-}$samples within the WCLs were identified using a custom in-house designed pipeline as previously described [66].

\section{Real-time PCR analysis}

Total RNA was extracted from snap frozen tissue using TRIzol (ThermoFisher Scientific, 15596026) or an RNeasy Kit (Qiagen, 74136) as per manufacturer instructions. Reverse transcription was performed using the High Capacity cDNA Reverse Transcription Kit (ThermoFisher Scientific, 4368813). Real-time PCR amplification was achieved using Taqman (Bioline, BIO-83020) and SYBR (Bioline, QT605-20) reagents. The Taqman probes used were: Bcl-g (Mm01261010_m1), Bcl2 (Mm00477631_m1), Mcl1 (Mm01257351_g1), Bcl-xl (Mm00437783_m1), Puma (Mm00519268_m1), Bim (Mm00437796_m1), Bax (Mm00432051_m1), Bakl (Mm00432045_m1), Tp53 (Mm01731290_g1), Muc2 (Mm00458299_m1), Muc13 (Mm00495397_m1), and Gapdh (Mm99999915_g1). The SYBR green primers used were: Clcal (F: 5'AACAACGGCTATGAGGGCAT-3', R: 5'-TGAGTCACCATGTCCTTTATGTGT-3'), Fcgbp (F: 5'GGCCTGGGGTAATGGGAAAG-3', R: 5'-GTCCA CACCGTTCACCTTGA-3'), Gapdh (F: 5'-CAACTCACT CAAGATTGTCAGCAA-3', R: 5'-TACTTGGCAGGTTT CTCCAGGC-3'), Mptxl (5'-GAGGGTTGCTGATCTCC CA-3', R: 5'-GCCTTTCCCTTCATGTCTGTTT-3'), BCL-G (short specific, F: 5'-CCAAAATTGTTGAGCTGCTG-3', R: 5'-CATCAAACCATCCTGTGGAA-3'), BCL-G (long and short 1, F: 5'- AGGGTCTCTCCTTCCAGCTC-3', R: 5'TCTTTCCAACTGATCTCCTGAA-3'), BCL-G (long and short 2, F: 5'-CCAAAATTGTTGAGCTGCTG-3', R: 5'CAGAGTAGGACAGCCCATCC-3') and GAPDH (F: 5' GTCGGAGTCAACGGATT-3'. R: 5'-AAGCTTCCCGT TCTCAG-3'). All samples were run on a Viia7 Real-Time PCR System (ThermoFisher Scientific). Target gene expression is expressed relative to the housekeeping gene expression $($ Gapdh $)$ is presented in arbitrary units $\left(2^{(-\Delta \mathrm{Ct})}\right)$.

\section{FACS analysis}

The colon was opened longitudinally and washed with PBS to remove feces and cut into $5 \mathrm{~mm}$ pieces. The samples were then incubated in $10 \mathrm{~mL}$ pre-digestion mix $(3 \mathrm{mM}$ EDTA, $1 \mathrm{mM}$ DTT, HBSS) for $20 \mathrm{~min}$ on ice. Mechanical release of epithelial cells was achieved by shaking for $30 \mathrm{~s}$, after which the supernatant was passed through a 100- $\mu$ m cell strainer into a new $50 \mathrm{~mL}$ tube and placed on ice. This was repeated twice with $5 \mathrm{~mL}$ pre-digestion mix, with pooling of the supernatant from previous steps. The tissue was then incubated in digestion $\operatorname{mix}(0.6 \mathrm{mg} / \mathrm{mL}$ collagenase/dispase, Sigma-Aldrich, HBSS) for $15 \mathrm{~min}$ at $37^{\circ}$ C. The samples were then shaken for $30 \mathrm{~s}$, and then supernatant was passed through a $100-\mu \mathrm{m}$ cell strainer and pooled with previous fractions. The cells collected from all flow through steps were then pelleted by centrifugation at 4 ${ }^{\circ} \mathrm{C}$ ( $5 \mathrm{~min}, 300 \mathrm{~g}$ ), and the cell pellet was resuspended in 3 mL FACS buffer for processing for flow cytometry and cell sorting. PI was added at a final concentration of $1 \mu \mathrm{g} / \mathrm{mL}$. Gating was performed to exclude doublet cells, PI-positive cells, and include LGR5-GFP-positive cells.

Lamina propria cells were isolated from colon by incubation in $1 \mathrm{mM}$ EDTA/ $\mathrm{Ca}^{2+} \mathrm{Mg}^{2+}$ free HBSS (ThermoFisher Scientific, 14170112) supplemented with $3 \%(\mathrm{v} / \mathrm{v})$ FCS for $30 \mathrm{~min}$ at $37^{\circ} \mathrm{C}$ with gentle shaking to remove epithelial cells. Colonic tissues were then minced and 
digested with $1 \mathrm{mg} / \mathrm{ml}$ of collagenase/dispase

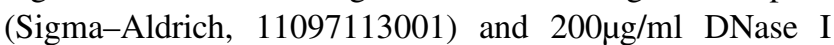
(Sigma-Aldrich, DN25-1G) in RPMI-1640 medium (ThermoFisher Scientific, 11875-093) supplemented with $3 \%$ (v/v) FCS for 45 mins at $37^{\circ} \mathrm{C}$ with gentle shaking. Digested cells were filtered through a $70-\mu \mathrm{m}$ cell strainer and mononuclear cells were isolated on a $37 \% / 80 \%$ Percoll gradient (Sigma-Aldrich, 17-0891-01). Leukocytes were recovered from the interface and washed twice with FACS buffer (1 mM EDTA, 3\% (v/v) FCS, PBS) before staining for FACS analysis.

Colonic single cell suspensions were stained with Fixable Viability Dye (ThermoFisher Scientific, 65-0866-18) to identify live cells. For surface marker staining, cells were stained with antibodies against the following markers: CD45.2 (BD Biosciences, BD560693), CD3e (ThermoFisher Scientific, 25-0031-81), CD4 (ThermoFisher Scientific, 17-0041-81), MHCII (BD Biosciences, BD563413), CD64 (BD Biosciences, BD558539), and CD11b (BD Biosciences, BD562317). Flow cytometry was performed with a LSRFortessa ${ }^{\mathrm{TM}}$ cytometer (BD Biosciences) and FlowJo analysis software (FlowJo).

\section{Reagents used for 3D colon and SI crypt culture}

DMEM-F12 with GlutaMAX (ThermoFisher Scientific, 10565018) supplemented with penicillin-streptomycin (ThermoFisher Scientific, 15140-122), 1× N2 (ThermoFisher Scientific, 17502), 1× B27 (ThermoFisher Scientific, 17504), and HEPES (10 mM), R-spondin-Fc Conditioned Medium (2\%), partially purified Wnt3a conditioned medium $(1 \% \mathrm{v} / \mathrm{v})$ (harvested from Wnt3A-expressing $\mathrm{L}$ cell line, ATCC no. CRL-2647 and affinity column purified as previously described [69]), recombinant human Noggin (100 ng/mL, PeproTech, 120-10), recombinant mouse EGF (50 ng/mL, PeproTech, 315-09) and Rho-kinase inhibitor Y27632 (10 $\mu \mathrm{M}$, Sigma-Aldrich, Y0503). R-spondin-Fc conditioned medium was harvested from $293 \mathrm{~F}$ cells (after 7 days) transiently transfected with a human R-spondin2 construct that has Fc-fusion protein fused to the C-terminus and cloned into pApex vector [70, 71]. Y27632 was only added for the first 4 days of colon cultures. SI cultures do not require Wnt $3 \mathrm{~A}$.

\section{Isolation of murine colon and small intestinal crypts}

Detailed procedures to isolate normal murine colon crypts have been described previously [72]. The colons from WT and $\mathrm{Bcl}-\mathrm{g}^{-1-}$ mice were sterilized in $0.04 \%(\mathrm{w} / \mathrm{v})$ sodium hypochlorite solution for $10 \mathrm{~min}$ at room temperature, washed with PBS and incubated with $5 \mathrm{ml}$ of chelation buffer ( $3 \mathrm{mM}$ EDTA, $0.05 \mathrm{mM}$ DTT in PBS) in for $60 \mathrm{~min}$ at room temperature. The colons were transferred in $2 \mathrm{~mL}$ PBS and the crypts were released into the PBS by manual shaking for $10 \mathrm{~s}$. The supernatant (PBS with crypts) was collected and the procedure repeated four times, each with $2 \mathrm{~mL}$ fresh PBS. The colon was then discarded and the supernatant pelleted at $1000 \mathrm{rpm}$ for $1 \mathrm{~min}$ at $4{ }^{\circ} \mathrm{C}$. The steps were similar for the small intestines (SI) except that they were incubated in chelation buffer for $5 \mathrm{~min}$ at $37^{\circ} \mathrm{C}$. The (SI) were then transferred into PBS and the villi were released by manual shaking 20 times, and the supernatant discarded. The SI fragments were then incubated in fresh chelation buffer for $20 \mathrm{~min}$ at room temperature. After which, the SI were transferred into PBS and manually shaken 20 times to release the SI crypts. This process was repeated three times, with the first round of supernatant discarded. The second and the third rounds of supernatants were pooled and pelleted down at $1000 \mathrm{rpm}$ for $1 \mathrm{~min}$ at $4{ }^{\circ} \mathrm{C}$.

\section{Crypt Culture setup}

The required wells of a 96-well plate (BD Falcon) were coated with $15 \mu \mathrm{L}$ of BD Matrigel $^{\mathrm{TM}}$ matrix (BD Bioscience, 356237). The Matrigel was allowed to polymerize by incubating for $30 \mathrm{~min}$ at $37^{\circ} \mathrm{C}$. Crypt fragment suspension (containing 200 crypts in $100 \mu \mathrm{L}$ volume) was added per well and incubated at $37^{\circ} \mathrm{C}$. The medium was replaced every other day.

\section{Crypt culture Microscopy and Image Processing}

Detailed image acquisition and analysis procedures for acquiring images in 96-well plates were previously described [73]. Bright field microscopy was conducted using a retrofitted Nikon Eclipse Ti-U microscope using a $\times 4$ objective lens and a motorized stage (Prior Scientific, H117). Bright field image stacks for each individual well were captured using a Nikon DS-Ri2 camera (Nikon Instruments Inc., MQA17000) driven by the NIS-Elements software (Nikon). The depth images of each FOV (well) were then stacked using the EDF algorithm in FIJI. Images were taken on most days for 9 days. The processed images were curated manually with the objects identified labelled either as $\mathrm{S}$ (spheroids) or $\mathrm{O}$ (organoids). The parameters were measured by drawing a line around the object. The average counts per well and the proportion of organoids were calculated.

\section{Statistical analysis}

All data is presented as mean \pm SEM and are representative of three or more experiments. Statistical significance was determined using a two-tailed Student's $t$-test or ANOVA (parametric or non-parametric) with Bonferroni's post-hoc as appropriate. 
Acknowledgements We would like to thank Associate Professor Joan Heath for critical review of the manuscript, the Walter and Eliza Hall Institute of Medical Research histology, microscopy, and animal facility staff for expert technical assistance and Denis Quilici for performing irradiation of mice. We would like to thank Associate Professor Kulmira Nurgali for providing the T4056 cell line. This project was funded by the Victorian State Government Operational Infrastructure Support Program and by the National Health and Medical Research Council (NHMRC) of Australia Program Grants (461221 and 1054925; PB), Project Grant (1051506; PB and TLP). OMS and PB are NHMRC Senior Research Fellows (1136119, 1042629), and TLP is a Victorian Cancer Agency Fellow and WEHI Dyson Bequest Centenary Fellow.

Author contributions PMN, LFD, and AP designed, performed, and analyzed experiments and assisted with manuscript preparation. NL, MG, KYF, KA, GvD, CWT, YH, HYKY, CGL, ARP, AD, CB, RF, SA, KM, RRJL, and MP performed experiments. ME, AIW, TB, and OMS supervised experiments and provided critical feedback. PB and TLP conceived the study, designed, performed, and analyzed experiments and wrote the manuscript.

\section{Compliance with ethical standards}

Conflict of interest The authors declare that they have no conflict of interest.

Publisher's note: Springer Nature remains neutral with regard to jurisdictional claims in published maps and institutional affiliations.

Open Access This article is licensed under a Creative Commons Attribution 4.0 International License, which permits use, sharing, adaptation, distribution and reproduction in any medium or format, as long as you give appropriate credit to the original author(s) and the source, provide a link to the Creative Commons license, and indicate if changes were made. The images or other third party material in this article are included in the article's Creative Commons license, unless indicated otherwise in a credit line to the material. If material is not included in the article's Creative Commons license and your intended use is not permitted by statutory regulation or exceeds the permitted use, you will need to obtain permission directly from the copyright holder. To view a copy of this license, visit http://creativecommons. org/licenses/by/4.0/.

\section{References}

1. Ruemmele FM, Seidman EG, Lentze MJ. Regulation of intestinal epithelial cell apoptosis and the pathogenesis of inflammatory bowel disorders. J Pedia Gastroenterol Nutr. 2002;34:254-60.

2. Canli O, Nicolas AM, Gupta J, Finkelmeier F, Goncharova O, Pesic M, et al. Myeloid cell-derived reactive oxygen species induce epithelial mutagenesis. Cancer Cell. 2017;32:869. e865

3. Eaden JA, Abrams KR, Mayberry JF. The risk of colorectal cancer in ulcerative colitis: a meta-analysis. Gut. 2001;48:526-35.

4. Adams JM, Cory S. The BCL-2 arbiters of apoptosis and their growing role as cancer targets. Cell Death Differ. 2017;25:27.

5. Fletcher JI, Meusburger S, Hawkins CJ, Riglar DT, Lee EF, Fairlie WD, et al. Apoptosis is triggered when prosurvival Bcl-2 proteins cannot restrain Bax. Proc Natl Acad Sci USA. 2008;105:18081.

6. Letai A, Bassik MC, Walensky LD, Sorcinelli MD, Weiler S, Korsmeyer SJ. Distinct BH3 domains either sensitize or activate mitochondrial apoptosis, serving as prototype cancer therapeutics. Cancer Cell. 2002;2:183-92.

7. Guo B, Godzik A, Reed JC. Bcl-G, a novel pro-apoptotic member of the Bcl-2 family. J Biol Chem. 2001;276:2780-5.

8. Giam M, Mintern JD, Rautureau GJ, Hinds MG, Strasser A, Bouillet P. Detection of Bcl-2 family member Bcl-G in mouse tissues using new monoclonal antibodies. Cell Death Dis. 2012;3: e378.

9. Giam M, Okamoto T, Mintern JD, Strasser A, Bouillet P. Bcl-2 family member Bcl-G is not a proapoptotic protein. Cell Death Dis. 2012;3:e404.

10. Kibel AS, Faith DA, Bova GS, Isaacs WB. Loss of heterozygosity at $12 \mathrm{P} 12-13$ in primary and metastatic prostate adenocarcinoma. $\mathrm{J}$ Urol. 2000;164:192-6.

11. Aissani B, Bonan C, Baccichet A, Sinnett D. Childhood acute lymphoblastic leukemia: is there a tumor suppressor gene in chromosome 12p12.3? Leuk Lymphoma. 1999;34:231-9.

12. Hatta Y, Takeuchi S, Yokota J, Koeffler HP. Ovarian cancer has frequent loss of heterozygosity at chromosome 12p12.3-13.1 (region of TEL and Kip1 loci) and chromosome 12q23-ter: evidence for two new tumour-suppressor genes. $\mathrm{Br} \mathrm{J}$ Cancer. 1997;75:1256-62.

13. Montpetit A, Boily G, Sinnett D. A detailed transcriptional map of the chromosome 12p12 tumour suppressor locus. Eur J Hum Genet. 2002;10:62-71.

14. Neufert C, Becker C, Neurath MF. An inducible mouse model of colon carcinogenesis for the analysis of sporadic and inflammation-driven tumor progression. Nat Protoc. 2007;2:1998-2004.

15. Tanaka T, Suzuki R, Kohno H, Sugie S, Takahashi M, Wakabayashi K. Colonic adenocarcinomas rapidly induced by the combined treatment with 2-amino-1-methyl-6-phenylimidazo[4,5b]pyridine and dextran sodium sulfate in male ICR mice possess beta-catenin gene mutations and increases immunoreactivity for beta-catenin, cyclooxygenase- 2 and inducible nitric oxide synthase. Carcinogenesis. 2005;26:229-38.

16. Wirtz S, Neufert C, Weigmann B, Neurath MF. Chemically induced mouse models of intestinal inflammation. Nat Protoc. 2007:2:541-6.

17. Moser AR, Pitot HC, Dove WF. A dominant mutation that predisposes to multiple intestinal neoplasia in the mouse. Sci (New York, NY). 1990;247:322-4.

18. Yamada Y, Mori H. Multistep carcinogenesis of the colon in Apc $(\mathrm{Min} /+)$ mouse. Cancer Sci. 2007;98:6-10.

19. Olsen J, Gerds TA, Seidelin JB, Csillag C, Bjerrum JT, Troelsen JT, et al. Diagnosis of ulcerative colitis before onset of inflammation by multivariate modeling of genome-wide gene expression data. Inflamm bowel Dis. 2009;15:1032-8.

20. Hussain SP, Amstad P, Raja K, Ambs S, Nagashima M, Bennett $\mathrm{WP}$, et al. Increased p53 mutation load in noncancerous colon tissue from ulcerative colitis: a cancer-prone chronic inflammatory disease. Cancer Res. 2000;60:3333-7.

21. Kern SE, Redston M, Seymour AB, Caldas C, Powell SM, Kornacki S, et al. Molecular genetic profiles of colitis-associated neoplasms. Gastroenterology. 1994;107:420-8.

22. Yoshida T, Mikami T, Mitomi H, Okayasu I. Diverse p53 alterations in ulcerative colitis-associated low-grade dysplasia: full-length gene sequencing in microdissected single crypts. J Pathol. 2003;199:166-75.

23. Takaku H, Ajioka Y, Watanabe H, Hashidate H, Yamada S, Yokoyama J, et al. Mutations of p53 in morphologically nonneoplastic mucosa of long-standing ulcerative colitis. Jpn J Cancer Res. 2001;92:119-26.

24. Fogt F, Vortmeyer AO, Goldman H, Giordano TJ, Merino MJ, Zhuang Z. Comparison of genetic alterations in colonic adenoma 
and ulcerative colitis-associated dysplasia and carcinoma. Hum Pathol. 1998;29:131-6.

25. Fearon ER, Vogelstein B. A genetic model for colorectal tumorigenesis. Cell. 1990;61:759-67.

26. Miled C, Pontoglio M, Garbay S, Yaniv M, Weitzman JB. A genomic map of p53 binding sites identifies novel p53 targets involved in an apoptotic network. Cancer Res. 2005;65:5096-104.

27. Leroy B, Girard L, Hollestelle A, Minna JD, Gazdar AF, Soussi T. Analysis of TP53 mutation status in human cancer cell lines: a reassessment. Hum Mutat. 2014;35:756-65.

28. Amcheslavsky A, Jiang J, Ip YT. Tissue damage-induced intestinal stem cell division in Drosophila. Cell Stem Cell. 2009;4:49-61.

29. Kuraishy A, Karin M, Grivennikov SI. Tumor promotion via injuryand death-induced inflammation. Immunity. 2011;35:467-77.

30. Barker N, van Es JH, Kuipers J, Kujala P, van den Born M, Cozijnsen $\mathrm{M}$, et al. Identification of stem cells in small intestine and colon by marker gene Lgr5. Nature. 2007;449:1003-7.

31. Vriesendorp HM, Vigneulle RM, Kitto G, Pelky T, Taylor P, Smith J. Survival after total body irradiation: effects of irradiation of exteriorized small intestine. Radiother Oncol. 1992;23:160-9.

32. Phesse TJ, Myant KB, Cole AM, Ridgway RA, Pearson H, Muncan V, et al. Endogenous c-Myc is essential for p53-induced apoptosis in response to DNA damage in vivo. Cell Death Differ. 2014;21:956-66.

33. Ernst M, Preaudet A, Putoczki T. Non-invasive Assessment of the Efficacy of New Therapeutics for Intestinal Pathologies Using Serial Endoscopic Imaging of Live Mice. J. Vis. Exp. 2015; e52383. https://doi.org/10.3791/52383.

34. McGuckin MA, Linden SK, Sutton P, Florin TH. Mucin dynamics and enteric pathogens. Nat Rev Microbiol. 2011;9:265-78.

35. Sheng YH, Hasnain SZ, Florin TH, McGuckin MA. Mucins in inflammatory bowel diseases and colorectal cancer. J Gastroenterol Hepatol. 2012;27:28-38.

36. Johansson ME, Thomsson KA, Hansson GC. Proteomic analyses of the two mucus layers of the colon barrier reveal that their main component, the Muc2 mucin, is strongly bound to the Fcgbp protein. J Proteome Res. 2009;8:3549-57.

37. Erickson NA, Nystrom EE, Mundhenk L, Arike L, Glauben R, Heimesaat MM, et al. The goblet cell protein Clca1 (Alias mClca3 or Gob-5) is not required for intestinal mucus synthesis, structure and barrier function in naive or DSS-challenged mice. PLOS ONE. 2015;10:e0131991.

38. van der Meer-van Kraaij C, Kramer E, Jonker-Termont D, Katan MB, nvan der Meer R, Keijer J. Differential gene expression in rat colon by dietary heme and calcium. Carcinogenesis. 2005;26:73-9.

39. Veis DJ, Sorenson CM, Shutter JR, Korsmeyer SJ. Bcl-2-deficient mice demonstrate fulminant lymphoid apoptosis, polycystic kidneys, and hypopigmented hair. Cell. 1993;75:229-40.

40. Motoyama N, Wang F, Roth KA, Sawa H, Nakayama K, Nakayama K, et al. Massive cell death of immature hematopoietic cells and neurons in Bcl-x-deficient mice. Science. 1995;267:1506-10.

41. Bouillet P, Metcalf D, Huang DC, Tarlinton DM, Kay TW, Kontgen F, et al. Proapoptotic Bcl-2 relative Bim required for certain apoptotic responses, leukocyte homeostasis, and to preclude autoimmunity. Science. 1999;286:1735-8.

42. Knudson CM, Tung KS, Tourtellotte WG, Brown GA, Korsmeyer SJ. Bax-deficient mice with lymphoid hyperplasia and male germ cell death. Science. 1995;270:96-9.

43. Dirisina R, Katzman RB, Goretsky T, Managlia E, Mittal N, Williams DB, et al. p53 and PUMA independently regulate apoptosis of intestinal epithelial cells in patients and mice with colitis. Gastroenterology. 2011;141:1036-45.
44. Qiu W, Carson-Walter EB, Kuan SF, Zhang L, Yu J. PUMA suppresses intestinal tumorigenesis in mice. Cancer Res. 2009;69:4999-5006

45. Scherr AL, Gdynia G, Salou M, Radhakrishnan P, Duglova K, Heller A, et al. Bcl-xL is an oncogenic driver in colorectal cancer. Cell Death Dis. 2016;7:e2342.

46. Yeretssian G, Correa RG, Doiron K, Fitzgerald P, Dillon CP, Green DR, et al. Non-apoptotic role of BID in inflammation and innate immunity. Nature. 2011;474:96-9.

47. Merritt AJ, Allen TD, Potten CS, Hickman JA. Apoptosis in small intestinal epithelial from p53-null mice: evidence for a delayed, p53-independent G2/M-associated cell death after gammairradiation. Oncogene. 1997;14:2759-66.

48. Vogelstein B, Lane D, Levine AJ. Surfing the p53 network. Nature. 2000;408:307-10.

49. Spehlmann ME, Manthey CF, Dann SM, Hanson E, Sandhu SS, Liu LY, et al. Trp53 deficiency protects against acute intestinal inflammation. J Immunol. 2013;191:837-47.

50. Chang WC, Coudry RA, Clapper ML, Zhang X, Williams KL, Spittle CS, et al. Loss of p53 enhances the induction of colitisassociated neoplasia by dextran sulfate sodium. Carcinogenesis. 2007;28:2375-81.

51. Fujii S, Fujimori T, Kawamata H, Takeda J, Kitajima K, Omotehara $\mathrm{F}$, et al. Development of colonic neoplasia in p53 deficient mice with experimental colitis induced by dextran sulphate sodium. Gut. 2004;53:710-6.

52. Allen A, Hutton DA, Pearson JP. The MUC2 gene product: a human intestinal mucin. Int J Biochem Cell Biol. 1998; 30:797-801.

53. Tytgat KM, Buller HA, Opdam FJ, Kim YS, Einerhand AW, Dekker J. Biosynthesis of human colonic mucin: Muc2 is the prominent secretory mucin. Gastroenterology. 1994;107: 1352-63.

54. Yang B, Cao L, Liu B, McCaig CD, Pu J. The transition from proliferation to differentiation in colorectal cancer is regulated by the calcium activated chloride channel A1. PLoS ONE. 2013;8: e60861.

55. Heazlewood CK, Cook MC, Eri R, Price GR, Tauro SB, Taupin $\mathrm{D}$, et al. Aberrant mucin assembly in mice causes endoplasmic reticulum stress and spontaneous inflammation resembling ulcerative colitis. PLoS Med. 2008;5:e54.

56. Van der Sluis M, De Koning BA, De Bruijn AC, Velcich A, Meijerink JP, Van Goudoever JB, et al. Muc2-deficient mice spontaneously develop colitis, indicating that MUC2 is critical for colonic protection. Gastroenterology. 2006;131:117-29.

57. Wenzel UA, Magnusson MK, Rydstrom A, Jonstrand C, Hengst J, Johansson ME, et al. Spontaneous colitis in Muc2-deficient mice reflects clinical and cellular features of active ulcerative colitis. PLoS ONE. 2014;9:e100217.

58. Zhang XN, Liu JX, Hu YW, Chen H, Yuan ZH. Hyper-activated IRF-1 and STAT1 contribute to enhanced interferon stimulated gene (ISG) expression by interferon alpha and gamma cotreatment in human hepatoma cells. Biochim Biophys Acta. 2006;1759:417-25.

59. Gupta BK, Maher DM, Ebeling MC, Sundram V, Koch MD, Lynch DW, et al. Increased expression and aberrant localization of mucin 13 in metastatic colon cancer. J Histochem Cytochem. 2012;60:822-31.

60. Shimamura T, Ito H, Shibahara J, Watanabe A, Hippo Y, Taniguchi $\mathrm{H}$, et al. Overexpression of MUC13 is associated with intestinal-type gastric cancer. Cancer Sci. 2005;96:265-73.

61. Walsh MD, Young JP, Leggett BA, Williams SH, Jass JR, McGuckin MA. The MUC13 cell surface mucin is highly expressed by human colorectal carcinomas. Hum Pathol. 2007;38: 883-92. 
62. Chauhan SC, Vannatta K, Ebeling MC, Vinayek N, Watanabe A, Pandey KK, et al. Expression and functions of transmembrane mucin MUC13 in ovarian cancer. Cancer Res. 2009;69:765-74.

63. Sheng YH, Lourie R, Linden SK, Jeffery PL, Roche D, Tran TV, et al. The MUC13 cell-surface mucin protects against intestinal inflammation by inhibiting epithelial cell apoptosis. Gut. 2011;60:1661-70.

64. Barrett T, Wilhite SE, Ledoux P, Evangelista C, Kim IF, Tomashevsky M, et al. NCBI GEO: archive for functional genomics data sets-update. Nucleic acids Res. 2013;41(Database issue): D991-5.

65. Wisniewski JR, Zougman A, Mann M. Combination of FASP and StageTip-based fractionation allows in-depth analysis of the hippocampal membrane proteome. J Proteome Res. 2009;8:5674-8.

66. Delconte RB, Kolesnik TB, Dagley LF, Rautela J, Shi W, Putz $\mathrm{EM}$, et al. CIS is a potent checkpoint in NK cell-mediated tumor immunity. Nat Immunol. 2016;17:816-24.

67. Cox J, Neuhauser N, Michalski A, Scheltema RA, Olsen JV, Mann M. Andromeda: a peptide search engine integrated into the MaxQuant environment. J Proteome Res. 2011;10:1794-805.
68. Cox J, Mann M. MaxQuant enables high peptide identification rates, individualized p.p.b.-range mass accuracies and proteomewide protein quantification. Nat Biotechnol. 2008;26: 1367-72.

69. Willert K, Brown JD, Danenberg E, Duncan AW, Weissman IL, Reya $\mathrm{T}$, et al. Wnt proteins are lipid-modified and can act as stem cell growth factors. Nature. 2003;423:448.

70. Evans MJ, Hartman SL, Wolff DW, Rollins SA, Squinto SP. Rapid expression of an anti-human C5 chimeric Fab utilizing a vector that replicates in COS and 293 cells. J Immunol Methods. 1995; 184:123-38.

71. Yip HYK, Tan CW, Hirokawa Y, Burgess AW. Colon organoid formation and cryptogenesis are stimulated by growth factors secreted from myofibroblasts. PLoS ONE. 2018;13:e0199412.

72. Hirokawa Y, Yip KHY, Tan CW, Burgess AW. Colonic myofibroblast cell line stimulates colonoid formation. Am J PhysiolGastrointest Liver Physiol. 2014;306:G547-56.

73. Tan CW, Hirokawa Y, Burgess AW. Analysis of Wnt signalling dynamics during colon crypt development in 3D culture. Sci Rep. 2015;5:11036. 